Hydrology and Earth System Sciences, 9, 225-241, 2005

www.copernicus.org/EGU/hess/hess/9/225/

SRef-ID: 1607-7938/hess/2005-9-225

European Geosciences Union

\title{
Comparative analysis of the actual evapotranspiration of Flemish forest and cropland, using the soil water balance model WAVE
}

\author{
W. W. Verstraeten ${ }^{1,3}$, B. Muys ${ }^{2}$, J. Feyen ${ }^{1}$, F. Veroustraete $^{3}$, M. Minnaert ${ }^{4}$, L. Meiresonne ${ }^{5}$, and A. De Schrijver ${ }^{4}$ \\ ${ }^{1}$ Laboratory of Soil and Water Management, Katholieke Universiteit Leuven, Vital Decosterstraat 102, 3000 Leuven, \\ Flanders, Belgium \\ ${ }^{2}$ Laboratory for Forest, Nature and Landscape Research, Katholieke Universiteit Leuven, Vital Decosterstraat 102, 3000 \\ Leuven, Flanders, Belgium \\ ${ }^{3}$ Flemish Institute for Technological Research, Centre for Remote Sensing and Earth Observation Processes, Boeretang 200, \\ $2400 \mathrm{Mol}$, Flanders, Belgium \\ ${ }^{4}$ Laboratory of Forestry, Ghent University, Geraardsbergse Steenweg 267, 9090 Gontrode, Flanders, Belgium \\ ${ }^{5}$ Institute for Forestry and Game Management (IBW), Gaverstraat 4, 9500 Geraardsbergen, Flanders, Belgium
}

Received: 15 April 2005 - Published in Hydrology and Earth System Sciences Discussions: 27 May 2005

Revised: 18 August 2005 - Accepted: 2 September 2005 - Published: 21 September 2005

\begin{abstract}
This paper focuses on the quantification of the green - vegetation related - water flux of forest stands in the temperate lowland of Flanders. The underlying reason of the research was to develop a methodology for assessing the impact of forests on the hydrologic cycle in comparison to agriculture. The tested approach for calculating the water use by forests was based on the application of the soil water balance model WAVE. The study involved the collection of data from 14 forest stands, the calibration and validation of the WAVE model, and the comparison of the water use $(W U)$ components - transpiration, soil and interception evaporation - between forest and cropland.

For model calibration purposes simulated and measured time series of soil water content at different soil depths, period March 2000-August 2001, were compared. A multiplesite validation was conducted as well. Actual tree transpiration calculated with sap flow measurements in three forest stands gave similar results for two of the three stands of pine (Pinus sylvestris L.), but WAVE overestimated the actual measured transpiration for a stand of poplar (Populus sp.).

A useful approach to compare the $W U$ components of forest versus cropland is scenario analysis based on the validated WAVE model. The statistical Profile Analysis method was implemented to explore and analyse the simulated $W U$ time series. With an average annual rainfall of $819 \mathrm{~mm}$, the results reveal that forests in Flanders consume more water than agricultural crops. A 30 years average of $491 \mathrm{~mm}$ for
\end{abstract}

Correspondence to: $\mathrm{W} . \mathrm{W}$. Verstraeten

(willem.verstraeten@vito.be)
10 forests stands versus $398 \mathrm{~mm}$ for 10 cropped agricultural fields was derived. The $W U$ components, on yearly basis, also differ between the two land use types (transpiration: $315 \mathrm{~mm}$ for forest and $261 \mathrm{~mm}$ for agricultural land use; soil evaporation: $47 \mathrm{~mm}$ and $131 \mathrm{~mm}$, for forest and cropland, respectively). Forest canopy interception evaporation was estimated at $126 \mathrm{~mm}$, while it was negligible for cropland.

\section{Introduction}

Knowledge on forest hydrology and particularly on the water use $(W U)$ of forest ecosystems in Flanders is scarce. To assess the impact of forests on the hydrology of catchments, a modelling approach was applied using as input meteorological parameters and information of the forest stand. The approach to calculate $W U$ or actual evapotranspiration ( $\left.E T_{\text {act }}\right)$, i.e. the sum of plant transpiration $\left(T_{\text {act }}\right)$, soil evaporation $\left(E_{\text {act }}\right)$ and canopy interception evaporation (INT), consisted in reconstructing the water balance of the forest stand applying a 1-dimensional soil water balance model. The aim of this study was to evaluate if this approach enables a reasonably accurate estimate of $E T_{\text {act }}$. A modelling based approach for estimating the $W U$ of forest ecosystems was preferred since forests in Flanders are very fragmented with forest patches frequently smaller than one hectare. Representative flux tower measurements (Bowen ratio) require large homogeneous stands. Given the fragmented stand, the strong boundary effects and the relatively low material cost of soil water mass flux measurements, preference was given to use a 1-dimensional atmosphere-crop-soil water balance model.

(C) 2005 Author(s). This work is licensed under a Creative Commons License. 
An additional advantage of this approach is that other processes linked to the water cycle such as transport of nitrate, sulphur and phosphorus in soils and plants can be modelled as well, given that the input data for the cycles of these minerals are available.

The study was funded by the Flemish Government who plans the afforestation of 10000 ha of agricultural land in the period 1997-2007. Previous justifies examination of the effect of this policy on the water balance of watersheds. At this moment, forested land represents only a small fraction $(11 \%)$ of Flanders in contrast to the land classified as agricultural area (56\%). A drastic change in land use, i.e. a shift from agricultural to forest land might considerably affect the surface water and groundwater resource systems.

Given the atmospheric water demand of a region, it is commonly accepted that differences exist in water use between agricultural crops and forest vegetation. It is generally assumed that the evapotranspiration from forests is larger than for any crop compared (Ladekarl, 1998). Bosch and Hewlett (1982) demonstrated an average reduction of water yield of approximately $25 \mathrm{~mm}$ per year for every $10 \%$ of catchment area covered with mature deciduous trees, compared to grassland or pioneer vegetation. For coniferous forests this would correspond with an average reduction of roughly $40 \mathrm{~mm}$ per year. But, Hall and Roberts (1990) demonstrated that the total water use of beech and ash forests on chalk and clay formations in southern Britain was lower than that of grassland. The annual stand transpiration for ash forest was $372 \mathrm{~mm}$ as opposed to $355 \mathrm{~mm}$ for beech forest (Roberts and Rosier, 1994). Also from satellite remote sensing (Landsat TM) in the Netherlands, during the summer of 1995, Bastiaanssen et al. (2001) found that evapotranspiration from land surfaces covered with coniferous and deciduous vegetation was lower than the water use of agricultural crops on all the assumed dates. Their figures reveal an average daily evapotranspiration of respectively $3.5,4$ and $3.5 \mathrm{~mm}$ for crops and 2,3 and $2.5 \mathrm{~mm}$ for forests. These examples from literature show that the effect of temperate forests on the hydrological balance is not unambiguous.

The overarching objective of this study was to assess for the soil and climatic conditions of Flanders the difference in water use of forests in comparison to agricultural land, using experimental data and the 1-dimensional field water balance WAVE (Vanclooster et al., 1994, 1996). Fourteen forest stands in Flanders, representing the main forest and soil types, were equipped with hydrological measuring equipment in order to derive tree transpiration and soil and canopy interception evaporation. Data on cropland were derived from literature. The experimental work served for the characterization of the model input and the state variables for calibrating and validating the model. The parameters for modelling the water use of forest and agricultural land were derived indirectly, through model calibration. After calibration and validation, the WAVE model was used to estimate the components of the water balance of forest stands and agricul- tural land for a 30-year period (1971-2000). In the scenarioanalysis the $W U$ of 10 forest stands and 10 agricultural fields were generated. The time series of the different $W U$ components of forest stands and agricultural fields were examined using the Profile Analysis method.

\section{Materials and methods}

\subsection{Model description}

The atmosphere-crop-soil water balance model WAVE (Water and Agrochemicals in soil, crop and Vadose Environment) was developed by Vanclooster et al. (1994 and 1996) and extensively calibrated and validated for the climatic conditions of Flanders and crops such as wheat, barley, maize, potato, sugar beet and grassland (Vanclooster et al., 1995; Ducheyne et al., 2001; Timmerman et al., 2001). WAVE is a physically based deterministic model that simulates the 1-dimensional transport of water and energy in the variably saturated root zone of the soil profile. For the crops listed above the model contains modules for simulating simultaneously the nitrogen balance and the crop response to water and nitrogen availability in the root zone. In Flanders, until recently the model has been sporadically used for the simulation of forest water fluxes of a poplar (Meiresonne et al., 1999) and a Scots pine stand (Meiresonne et al., 2003), with both applications being validated by sap flow measurements.

The water transport module of WAVE is based on the well-known Richards equation for homogeneous, isotropic, isothermal, rigid and porous media. The soil parameters needed in this module are the water retention curve and the hydraulic conductivity function for the different horizons explored by the root system. Several parametric models exist for describing the soil hydraulic functions. In this paper the retention curve of van Genuchten (van Genuchten, 1980) and the hydraulic conductivity function of Mualem (1976) were used. The model parameters of the soil hydraulic functions were derived from laboratory measurements using undisturbed soil samples.

A Neuman boundary condition was assumed at the top of the soil profile, whereby the flux at the soil surface is the result of the infiltration and the evaporative flux. As long as the soil water conditions are not limiting, the flux is calculated as a balance of potential evaporation, rain, interception and ponding. However, when the soil is saturated by excess of rainfall or when prolonged soil evaporation occurs, the flux condition is changed to a pressure or Dirichlet condition. To solve the soil moisture equation at the bottom of the soil compartment the lower boundaries must be known. In this study, the applied bottom boundary conditions are time series of depth of the water table, pressure heads or in case of a very deep water table, the assumption of free drainage.

The procedure to asses actual evapotranspiration in WAVE is based on the maximum outgoing water flux of the upper 
boundary condition of the Richards equation. First the potential evapotranspiration of a specific crop $\left(E T_{c}\right)$ is calculated as the product of the reference evapotranspiration $\left(E T_{0}\right)$ and the crop coefficient $\left(K_{c}\right)$, as outlined in the Eqs. (1) and (2) (Doorenbos and Pruitt, 1977; Allen et al., 1998):

$$
E T_{c}=K_{c} \cdot E T_{0}
$$

with

$$
E T_{0}=\frac{0.408 \Delta\left(R_{n}-G_{0}\right)+\gamma \frac{900}{(T+273)} u_{2}\left(e_{s}-e_{a}\right)}{\Delta+\gamma\left(1+0.34 u_{2}\right)}
$$

where $E T_{0}\left[\mathrm{~mm} \mathrm{~d}^{-1}\right]$ is the reference crop evapotranspiration corresponding to water consumption of a full grown short grass cover without restriction of water and nutritional elements uptake (Choisnel et al., 1992). $E T_{0}$ expresses the amount of water transferred from the vegetation-soil system to the atmosphere governed by meteorological and plant factors. Time series of $E T_{0}$ is input in the WAVE model and can be calculated with Eq. (2) where $R_{n}$ is the net radiation $\left[\mathrm{MJ} \mathrm{m}{ }^{-2} \mathrm{~d}^{-1}\right], G_{0}$ is the soil heat flux $\left[\mathrm{MJ} \mathrm{m}^{-2} \mathrm{~d}^{-1}\right.$ ] (on a daily basis set to zero), $T$ is the air temperature $2 \mathrm{~m}$ above the surface $\left[{ }^{\circ} \mathrm{C}\right], u_{2}$ is the wind velocity measured $2 \mathrm{~m}$ above the surface $\left[\mathrm{m} \mathrm{s}^{-1}\right], \Delta$ is the slope of the vapour pressure curve $\left[\mathrm{kPa}{ }^{\circ} \mathrm{C}^{-1}\right], \gamma$ is the psychometric constant $\left[\mathrm{kPa}^{\circ} \mathrm{C}^{-1}\right]$, and $e_{s}$ and $e_{a}$ are respectively the saturation and actual vapour pressure $[\mathrm{kPa}]$ (Allen et al., 1998).

$K_{c}$ is the crop factor converting the reference evapotranspiration $\left(E T_{0}\right)$ to the potential evapotranspiration $\left(E T_{c}\right)$ of the crop under consideration and depends on and varies with the crop development stage, which often is related to the Leaf Area Index $(L A I)$. The crop factor lumps together resistance to transpiration, crop height, crop roughness, reflection and crop rooting. The $K_{c}$ series of for instance broadleaf species are low in winter and high in summer. The $K_{c}$ series of evergreen conifer species vary less during the year. The $K_{c}$ factor, using $L A I$ measurements, was interpolated between its minimum (wintertime) and maximum (summertime) value during spring and between its maximum and minimum value during autumn.

$E T_{c}$ refers to the evaporation demand of crops growing in large fields under optimum soil water, management and environmental conditions. It is a lumped parameter including potential transpiration $\left(T_{p}\right)$, potential soil evaporation $\left(E_{p}\right)$ and canopy interception evaporation (INT). Since forest canopy interception water will evaporate before soil evaporation occurs, $E_{p}$ is calculated as a fraction of $\left(E T_{c}-I N T\right)$. This fraction is a function of the Leaf-Area Index ( $L A I)$ based on light extinction in canopies, or:

$E_{p}=\left(E T_{c}-I N T\right) \cdot \exp (-c \cdot L A I)$

where $c$ is a parameter accounting for the interception of incoming solar radiation by the vegetation set equal to 0.6 , a value very much in agreement with the value given by Huygen et al. (1997). Generally, the higher the LAI, the less radiation can reach the soil surface and thus the lower the soil evaporation.

The potential crop transpiration $\left(T_{p}\right)$ is then calculated as $E T_{c}$ reduced by evaporation of the intercepted water and the soil evaporation, or:

$T_{p}=E T_{c}-E_{p}-I N T$

where $I N T$ is the canopy water evaporation. $T_{p}$ is reduced to an actual level $\left(T_{\text {act }}\right)$ based on the prevailing moisture conditions in the root zone between surface $(0)$ and the maximum root depth $(L)$. The maximum root water uptake rate, $S_{\max }(z)$, at a given depth $z$ was defined according to Feddes et al. (1978). The soil pressure head $(h)$ and saturation level will reduce $S_{\max }$ with a factor $\alpha(h)$ resulting in the actual water extraction function $S(h, z) . \quad S_{\max }(z)$ is based on the crop root distribution in the soil profile and was determined from visual observations on the root distribution in soil profile pits. The root distribution function for water extraction in each soil layer was put directly proportional to the root density and the soil water content in that layer. The reduction function $\alpha(h)$ is written as (Belmans et al., 1983):

$$
\begin{aligned}
& \alpha(h)=0 \text { for } h_{W P}<h(z)<h_{0} \\
& \alpha(h)=\left(\frac{h(z)-h_{0}}{h_{F C}-h_{0}}\right)^{a} \text { for } h_{o}<h(z)<h_{F C} \\
& \alpha(h)=1-\left(\frac{h(z)-h_{c}}{h_{W P}-h_{c}}\right)^{a} \text { for } h_{c}<h(z)<h_{W P} \\
& \alpha(h)=1 \text { for } h_{F C}<h(z)<h_{c}
\end{aligned}
$$

where $h_{W P}, h_{F C}, h_{c}$ and $h_{0}$ are respectively the soil water pressure head at wilting point, field capacity, critical point where water extraction starts to reduce and saturation. $a$ is a shape parameter determining the linearity or hyperbolic form of the reduction function $\alpha(h)$. For broadleaf and conifer forest species, $h_{c}$ was put respectively equal to -1000 and $-2000 \mathrm{~cm}$. $T_{\text {act }}$ was calculated as:

$T_{\text {act }}=\int_{0}^{L} S(h, z) d z \leq T_{p}$

The actual soil evaporation ( $\left.E_{\mathrm{act}}\right)$ is the reduction of $E_{p}$ taking into account the soil water pressure head in the upper soil layer. Since in this study it is assumed that $E T_{\text {act }}$, the sum of the actual transpiration and actual evaporation, and the evaporation of the water intercepted by the canopy, stands for the water use $(W U)$ of the vegetation, the latter is given by:

$$
W U=E T_{\text {act }}=T_{\text {act }}+E_{\text {act }}+I N T
$$




\subsection{Model calibration and validation}

Generally calibration is the iterative process of adjusting the sensitive model parameters until statistical criteria, measuring the agreement between observations and simulated values, reach their optimal value. Manual calibration involves model parameterisation, choice of the calibration parameters based on a sensitivity analysis of the model and the specification of calibration criteria. Matching measured and modelled time series of soil moisture content (SMC), by tuning model parameters, was selected as a single criterion for calibration. The main drawback of manual calibration is the absence of a generally accepted objective criterion for comparison (Anderson and Woessner, 1992). To a certain extent, multi-criteria performance evaluation deals with this issue. Because different statistical indicators address different aspects of the measured set of data, such a multi-criteria approach will yield a more nuanced answer. The same issue of objective evaluation is raised with the validation of a calibrated model. Model performance should be evaluated using appropriate test statistics. Test statistics extract essential information from large data sets and reflect theirproperties into a limited number of indicators (Chow et al., 1993). The Root Mean Square Error (RMSE), Model efficiency $(M E)$ and Coefficient of Determination $(C D)$ were the simulation statistics applied during model calibration and validation. The formulae of the statistics are given in the following:

$R M S E=\sqrt{\frac{\sum_{i=1}^{n}\left(O_{i}-P_{i}\right)^{2}}{n}}$

$M E=1-\frac{\sum_{i=1}^{n}\left(O_{i}-P_{i}\right)^{2}}{\sum\left(O_{i}-\bar{O}\right)^{2}}$

$C D=\frac{\sum_{i=1}^{n}\left(O_{i}-\bar{O}\right)^{2}}{\sum_{i=1}^{n}\left(P_{i}-\bar{O}\right)^{2}}$

where $O_{i}$ is the $\mathrm{i}^{\text {th }}$ measured value, $P_{i}$ is $\mathrm{i}^{\text {th }}$ simulated value, $n$ is the total amount of available measurements in the considered time interval, and $\bar{O}$ is the average of the observations.

$R M S E$ is a measure of the residual standard deviation and should be as small as possible (optimally 0). The RMSE is a maximum likelihood estimator under the assumption that the measurement errors are normally distributed with a mean value equal to zero and a constant variance.

$M E$ measures the correlation between observed and simulated data and should optimally be one. If $0<M E<1$, then the modelling results are acceptable; if $M E=0$, then the average of the observed values is as good as the model; and if $M E<0$, then taking the average of the observed values gives better results and the model should be rejected.
$C D$ deals with the proportion of the total variance of observed data that is explained by the simulated data and should optimally be one. $C D$ indicates the performance related to the simulation of extreme values in the time series. As such, $C D$ is considered as an indicator of the quality of the simulation of extreme values in soil water content, occurring when the evapotranspiration demand is highest, or after a dry period when intensive rainfalls are observed. The model over- or underestimates the observed values if respectively $0 \leq C D<1$, and if $C D>1$.

The calibration and validation procedures described in this paper consist of a sensitivity analysis of the model parameters, manual model calibration using simulated and measured time series of soil water content at different depths of the soil profile (March 2000-August 2001) and multi-site validations, i.e. using the calibrated parameters from one site at other experimental sites during the same time period.

The selection of the model calibration parameters was based on the sensitivity analysis of the WAVE model parameters by Ducheyne et al. (2001). Those parameters are the crop factor $\left(K_{c}\right)$, the saturated hydraulic conductivity $\left(K_{\mathrm{sat}}\right)$, the root distribution function and the saturated volumetric soil water content $\left(S M C_{s}\right)$. The measured saturated hydraulic conductivity $K_{\text {sat }}$ is highly variable and site dependent (Vanderborght et al., 2001; Verstraeten et al., 2001) and can rarely taken as the hydraulic conductivity measured in the laboratory on undisturbed Kopecky ring samples. In reality, this parameter is $5-10 \%$ lower than the conductivity measured in laboratory, which according to van Genuchten et al. (1991) is due to the non-continuity of macro pores and/or the enclosures of air in the soil pore network. The crop factor $\left(K_{c}\right)$ of forest stands cannot be determined with the approach commonly used for agricultural crops. Lysimeter experiments are inappropriate for large trees. Before tuning the $K_{c}$ parameter series, representative $K_{c}$ values ought to be defined for the different forests stands. The procedure of Gochis and Cuenca (2000) was implemented. Weekly $K_{c}$ values were calculated from weekly evapotranspiration values derived as a residual value in the soil water balance (with water flux components measured at the experimental sites) and the reference evapotranspiration derived using the FAO 56 approach (Allen et al., 1998). It was assumed that the tree crop factor is in the same order as the crop factor for agricultural crops given that the root density of water extracting roots of agricultural crops and forest per unit land surface are similar. In general the root density in the X-Y plane of agricultural crops is larger than the spatial root densities of forest tree roots, however the root system of forest trees is much deeper (Mohren and van de Veen, 1995). The manual calibration procedure involved the following steps:

(i) $S M C_{s}$, measured under laboratory conditions, was lowered to the soil moisture values measured during the wettest period in winter with TDR sensors fixed at different depths in the soil profile; 
(ii) The time series of $K_{c}$ was tuned by comparing measured with simulated soil moisture profiles; and

(iii) To derive the root water uptake function, a soil root profile description (based on observations in a soil profile pit) was conducted to obtain qualitative root density data and hence measured and simulated soil water contents were compared at different soil depths.

These steps are not strictly separated, taking into account the strong mutual interactions between the model parameters.

\subsection{Field plots for model calibration and validation}

Fourteen forest stands (Pinus sylvestris L., Populus sp., Fagus sylvatica L., Fraxinus excelsior L., Quercus robur L.) were equipped and monitored during the period October 1999 to November 2001. The forest stands are located between $51^{\circ} 24^{\prime} 30^{\prime \prime}$ and $50^{\circ} 45^{\prime} 30^{\prime \prime} \mathrm{N}$ and between $3^{\circ} 47^{\prime} 00^{\prime \prime}$ and $4^{\circ} 49^{\prime} 30^{\prime \prime} \mathrm{E}$. The height above sea level ranges between 5 and $129 \mathrm{~m}$. The soil types are Regosol, Podzol, Podzoluvisol, Cambisol and Luvisol (Table 1, upper section). Their date of establishment varies between 1875 and 1984 and their area between 1 and 5 ha. The measurement campaign started on 1 March 2000 and lasted till 31 August 2001.

Per diagnostic soil horizon six undisturbed soil samples were taken (Kopecky rings, $5.1 \mathrm{~cm}$ height, $5 \mathrm{~cm}$ diameter, $100 \mathrm{~cm}^{3}$ volume) for the determination of the water retention curve and the hydraulic conductivity relation using standard laboratory methods (Klute, 1986). To monitor the soil moisture content $(S M C)$ of each soil layer, two Time Domain Reflectometery sensors (TDR, 3 pins, $50 \mathrm{~cm}$ ) (Topp et al., 1980) were installed horizontally $50 \mathrm{~cm}$ apart. Gravimetric soil samples in each soil layer were taken to calibrate the TDR sensors. Ten throughfall collectors (a funnel positioned $1 \mathrm{~m}$ above the surface connected with a bottle buried in the soil), each ten meters apart and positioned in a cross pattern (six collectors and four perpendicular to the six) (ICPforests conformity), two tensiometers (at the bottom of the root zone) or, if a groundwater table is present within the 2 to $4 \mathrm{~m}$ one groundwater level tube was installed. A standard setup of the instrumentation is depicted in Fig. 1.

The WAVE model was calibrated using the monitored data of eight experimental plots (plots 1-8). Six plots were used for validation purposes. In the forest stands used for calibration, stemflow devices were installed on three representative trees. The model trees were selected based on the average and the average plus and minus the standard deviation stem diameters at breast height, calculated on all the trees within a $100 \mathrm{~m}^{2}$ plot. Total rainfall (tipping bucket, Ecotechnic, the Netherlands), throughfall $(T F)$, stemflow $(S F)$ (only on the calibration plots), SMC profile (Tektronix 1502B, Redmond, USA) and the groundwater level (Eijkelkamp, the Netherlands) or soil water pressure head in the bottom compartment (Thies CLIMA, Germany) were measured weekly. During the dormant season (1 November till 28 February) the mea-

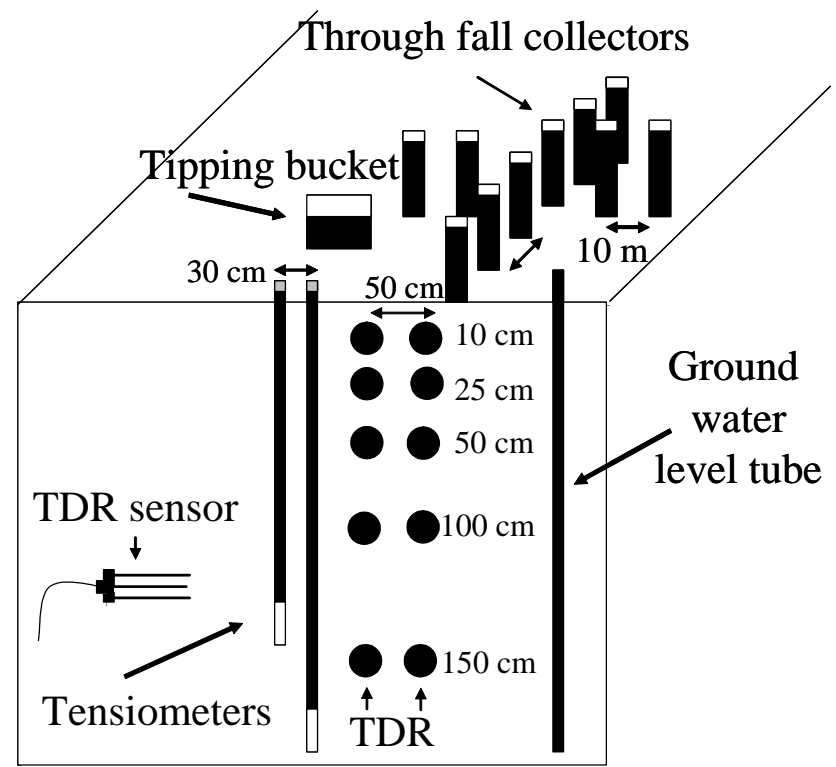

Fig. 1. Schematic view of the experimental setup of TDR sensors, tensiometers, throughfall collectors, tipping bucket for total rainfall, and water table observation tube.

surements were made fortnightly. Total rainfall was measured in nearby open field plots such that neither vegetation nor any obstacle did intercept rain. $S F$ was measured using a stemflow water collection system, consisting of a coiled gutter configured around the stem. To construct seasonal Plant Area Index $(P A I)$ time series, canopy images were taken using a hemispherical lens (Nikon Fisheye Converter FC-E8), mounted on a digital camera (Nikon digital camera COOLPIX 950). Special attention was given to leaf clumping when calculating Leaf Area Index ( $L A I)$ from digital imagery with LICOR type formulas. These formulas calculate the gap fraction, using light extinction models to describe the probability of interception of radiation within canopy layers, as well as the probability of sun flecks at the bottom of the canopy. The Poisson model was used assuming that projections of leaves are randomly located in the plane of the projection. Corrections for stems and branches were not performed, therefore we further use the term Plant Area Index $(P A I)$. Further details of data analysis are given in Sect. 2.4.

The measured data and applied models were assumed to be representative at field level. During the campaign, almost two measurements a week were conducted at plot 1,2 and 3 (see also Table 1). The soil physical characteristics of the 14 plots can be found in Verstraeten et al. (2001). The reference evapotranspiration was calculated using the PenmanMonteith method as described by Allen et al. (1998). Meteorological data of the nearest weather station of the Royal Meteorological Institute of Belgium were used. 
Table 1. Statistics [Root Mean Square Error (RMSE), Model Efficiency $(M E)$ and the Coefficient of Determination $(C D)$ ] of measured and simulated volumetric soil moisture content $(S M C)$ for soil profiles and minimum and maximum ranges at different depths of the calibration and validation plots; tree species, soil type, location (latitude/longitude) and height above sea level (a.s.l.) are also given.

\begin{tabular}{|c|c|c|c|c|c|c|c|c|c|c|c|c|c|c|}
\hline & \multicolumn{2}{|c|}{$\begin{array}{c}1 \\
\text { Pinus sylvestris }\end{array}$} & \multicolumn{2}{|c|}{$\begin{array}{c}2 \\
\text { Pinus sylvestris }\end{array}$} & \multicolumn{2}{|r|}{$\begin{array}{c}3 \\
\text { Populus sp. }\end{array}$} & \multicolumn{2}{|c|}{$\begin{array}{c}4 \\
\text { Fagus sylvatica } \\
\text { Quercus robur }\end{array}$} & \multicolumn{2}{|c|}{$\begin{array}{c}5 \\
\text { Fagus sylvatica } \\
\text { Quercus robur }\end{array}$} & \multicolumn{2}{|c|}{$\begin{array}{c}6 \\
\text { Fraxinus excelsior }\end{array}$} & $\begin{array}{c}7 \\
\text { Fagus sylvatica }\end{array}$ & $\begin{array}{c}8 \\
\text { Quercus robur }\end{array}$ \\
\hline $\begin{array}{c}\text { FAO soils } \\
\text { Latitude } \\
\text { Longitude } \\
\text { Height (a.s.l.) }\end{array}$ & $\begin{array}{r}\text { Um } \\
51 \\
4\end{array}$ & $\begin{array}{l}\text { oric Regosol } \\
{ }^{1} 18^{\prime} 30^{\prime \prime} \mathrm{N} \\
31^{\prime} 00^{\prime \prime} \mathrm{E} \\
16 \mathrm{~m}\end{array}$ & & $\begin{array}{l}\text { mbric Regosol } \\
51^{\circ} 18^{\prime} 30^{\prime \prime} \mathrm{N} \\
4^{\circ} 31^{\prime} 00^{\prime \prime} \mathrm{E} \\
16 \mathrm{~m}\end{array}$ & $\begin{array}{r}\text { Stagn } \\
5 \\
3\end{array}$ & $\begin{array}{l}\text { nic Podzoluvisol } \\
5^{\circ} 55^{\prime} 00^{\prime \prime} \mathrm{N} \\
3^{\circ} 47^{\prime} 00^{\prime \prime} \mathrm{E} \\
45 \mathrm{~m}\end{array}$ & & $\begin{array}{l}\text { yic Cambisol } \\
0^{\circ} 59^{\prime} 00^{\prime \prime} \mathrm{N} \\
{ }^{\prime} 49^{\prime} 00^{\prime \prime} \mathrm{E} \\
21 \mathrm{~m}\end{array}$ & $\begin{array}{r}\text { Gle } \\
5 \\
3\end{array}$ & $\begin{array}{l}\text { ic Cambisol } \\
{ }^{\circ} 59^{\prime} 00^{\prime \prime} \mathrm{N} \\
49^{\prime} 00^{\prime \prime} \mathrm{E} \\
21 \mathrm{~m}\end{array}$ & $\begin{array}{r}\text { Gleyic } \\
50 \\
3\end{array}$ & $\begin{array}{l}\text { Eutric Cambisol } \\
{ }^{\circ} 59^{\prime} 00^{\prime \prime} \mathrm{N} \\
049^{\prime} 00^{\prime \prime} \mathrm{E} \\
21 \mathrm{~m}\end{array}$ & $\begin{array}{c}\text { Dystric Podzoluvisol } \\
50^{\circ} 45^{\prime} 30^{\prime \prime} \mathrm{N} \\
4^{\circ} 24^{\prime} 30^{\prime \prime} \mathrm{E} \\
100 \mathrm{~m}\end{array}$ & $\begin{array}{c}\text { Haplic Luvisol } \\
50^{\circ} 48^{\prime} 00^{\prime \prime} \mathrm{N} \\
4^{\circ} 42^{\prime} 30^{\prime \prime} \mathrm{E} \\
65 \mathrm{~m}\end{array}$ \\
\hline $\begin{array}{c}\text { Statistic } \\
\text { RMSE (-) } \\
M E(-) \\
C D(-)\end{array}$ & $\begin{array}{c}\text { Soil profile } \\
0.01 \\
0.79 \\
0.68\end{array}$ & $\begin{array}{c}\text { (range soil layers) } \\
(0.01-2.21) \\
(-0.41-0.71) \\
(0.64-1.44)\end{array}$ & $\begin{array}{l}1.52 \\
0.72 \\
1.51\end{array}$ & $\begin{array}{c}(1.08-3.45) \\
(-0.67-0.78) \\
(0.58-2.17)\end{array}$ & $\begin{array}{l}0.74 \\
0.79 \\
1.93\end{array}$ & $\begin{array}{l}(0.55-1.78) \\
(0.28-0.86) \\
(1.10-4.93)\end{array}$ & $\begin{array}{l}5.20 \\
0.76 \\
0.81\end{array}$ & $\begin{array}{l}(1.43-2.86) \\
(0.35-0.96) \\
(1.40-6.50)\end{array}$ & $\begin{array}{l}1.60 \\
0.98 \\
4.01\end{array}$ & $\begin{array}{l}(0.57-3.62) \\
(0.50-1.00) \\
(0.76-1.30)\end{array}$ & $\begin{array}{l}1.53 \\
0.05 \\
0.44\end{array}$ & $\begin{array}{c}(0.91-6.33) \\
(-1.22-0.80) \\
(0.18-3.61)\end{array}$ & $\begin{array}{lc}2.03 & (1.42-5.02) \\
0.10 & (-3.44-0.65) \\
0.60 & (0.11-1.19)\end{array}$ & $\begin{array}{lc}1.25 & (1.19-2.39) \\
0.24 & (-1.58-0.62 \\
0.42 & (0.29-1.03)\end{array}$ \\
\hline & $\begin{array}{r}\text { Validation } \\
F a g\end{array}$ & $\begin{array}{l}\text { lots } \\
9 \\
\text { us sylvatica }\end{array}$ & & $\begin{array}{c}10 \\
\text { 2uercus robur }\end{array}$ & & $\begin{array}{c}11 \\
\text { Populus sp. }\end{array}$ & & $\begin{array}{c}12 \\
\text { gus sylvatica }\end{array}$ & & $\begin{array}{l}13 \\
\text { us sylvestris }\end{array}$ & & $\begin{array}{c}14 \\
\text { inus nigra }\end{array}$ & & \\
\hline $\begin{array}{l}\text { FAO soils } \\
\text { Latitude } \\
\text { Longitude } \\
\text { Height (a.s.l.) }\end{array}$ & $\begin{array}{r}\text { Gleyic A } \\
51 \\
3\end{array}$ & $\begin{array}{l}\text { ntropic Cambisol } \\
{ }^{\circ} 04^{\prime} 30^{\prime \prime} \mathrm{N} \\
02^{\prime} 30^{\prime \prime} \mathrm{E} \\
22 \mathrm{~m}\end{array}$ & & $\begin{array}{l}\text { leyic Cambisol } \\
51^{\circ} 09^{\prime} 00^{\prime \prime} \mathrm{N} \\
3^{\circ} 52^{\prime} 30^{\prime \prime} \mathrm{E} \\
5 \mathrm{~m}\end{array}$ & & $\begin{array}{l}\text { eyic Cambisol } \\
50^{\circ} 54^{\prime} 30^{\prime \prime} \mathrm{N} \\
4^{\circ} 09^{\prime} 30^{\prime \prime} \mathrm{E} \\
35 \mathrm{~m}\end{array}$ & $\begin{array}{r}\text { Dyst } \\
5 \\
\end{array}$ & $\begin{array}{l}\text { ic Podzoluvisol } \\
0^{\circ} 45^{\prime} 30^{\prime \prime} \mathrm{N} \\
27^{\prime} 30^{\prime \prime} \mathrm{E} \\
129 \mathrm{~m}\end{array}$ & & $\begin{array}{l}\text { ric Podzol } \\
0^{\circ} 09^{\prime} 30^{\prime \prime} \mathrm{N} \\
59^{\prime} 30^{\prime \prime} \mathrm{E} \\
22 \mathrm{~m}\end{array}$ & & $\begin{array}{l}\text { plic Podzol } \\
{ }^{\circ} 24^{\prime} 30^{\prime \prime} \mathrm{N} \\
04^{\prime} 00^{\prime \prime} \mathrm{E} \\
30 \mathrm{~m}\end{array}$ & & \\
\hline $\begin{array}{c}\text { Statistic } \\
\text { RMSE (-) } \\
M E(-) \\
C D(-)\end{array}$ & $\begin{array}{c}\text { Soil profile } \\
2.97 \\
0.58 \\
1.01\end{array}$ & $\begin{array}{c}\text { (range soil layers) } \\
(3.56-7.86) \\
(-9.52-0.66) \\
(0.08-2.85)\end{array}$ & $\begin{array}{l}4.02 \\
0.51 \\
2.17\end{array}$ & $\begin{array}{l}(3.90-5.71) \\
(0.33-0.54) \\
(1.47-4.80)\end{array}$ & $\begin{array}{l}3.04 \\
0.29 \\
1.43\end{array}$ & $\begin{array}{c}(2.06-12.81) \\
(-0.07-0.79) \\
(0.31-2.91)\end{array}$ & $\begin{array}{c}2.78 \\
-1.09 \\
0.20\end{array}$ & $\begin{array}{c}(1.98-3.88) \\
(-13.13-0.56) \\
(0.06-0.65)\end{array}$ & $\begin{array}{c}2.37 \\
-3.69 \\
0.24\end{array}$ & $\begin{array}{c}(2.03-5.16) \\
(-5.41-0.28) \\
(0.17-3.90)\end{array}$ & $\begin{array}{c}1.02 \\
-0.17 \\
0.45\end{array}$ & $\begin{array}{c}(0.62-4.53) \\
(-2.39-0.38) \\
(0.21-2.00)\end{array}$ & & \\
\hline
\end{tabular}

\subsection{Canopy interception and Leaf Area Index determina-} tion

The amount of water intercepted by the canopy was derived from the canopy water balance. Daily total rainfall, weekly throughfall $(T F)$ and stemflow $(S F)$ were measured in situ. Because of the large sampling interval, the distance between the total rainfall collector and the forest stand (2 to $10 \mathrm{~km})$ and the impacts of obstacles such as hedges, fences, trees and houses on the measurements, negative interception amounts were occasionally obtained. Hence, the weekly values were disaggregated with a similar technique as used for the disaggregation of rainfall data. In a first step splits weekly measurements of $T F$ and $S F$ were split into daily values using linear interpolation with daily total rainfall. Then linear regression coefficients (intercept set to zero) were derived from the (interpolated) daily $T F$ and $S F$ with daily total rainfall for different periods according to the evolution of $L A I$. Four periods were delineated: $i=1$ from 15 November to 30 March; $i=2$ from 1 April to 14 June; $i=3$ from 15 June to 14 September; and $i=4$ from 15 September to 14 November. The resulting correlation coefficients (slopes) were used to derive daily interception amounts by implementing the canopy water balance formula (Eq. 11):

$I N T_{i d}=T R_{d} \cdot\left(1-T F_{i}-S F_{i}\right)$

where $T F_{i}$ is the throughfall coefficient (-) for period $i, S F_{i}$ the stemflow coefficient (-) for period $i, T R_{d}$ is the daily total rainfall $(\mathrm{mm})$ and $I N T_{i d}$ the daily interception depth $(\mathrm{mm})$ derived with coefficients for period $i$. The subscript $i$ refers to one of the four periods cited earlier.

The LAI derived from hemispherical digital canopy photograph images (HDP). In fact, HDP provides Plant Area In- dices $(P A I)$ because leaves, stems and branches are imaged without distinction. Standard methods were used to determine the PAI from the HDP imagery (extracting the blue channel of the optical spectrum, determining threshold values to distinguish plant area from sky fractions) (Jonckheere et al., 2004a, b; Weiss et al., 2004). An automated procedure to analyze hundreds of hemispherical digital images was developed by Nackaerts (2002). Clumping of biomass was dealt with by applying the fractal dimension of the canopy image as correction factors (Nackaerts, 2002). The implementation of fractal dimension in $L A I$ estimation resulted in a model able to explain $88 \%$ of the variation in indirectly measured $L A I$, as reported by Nackaerts et al. (2001) for an experiment in a pine forest. Jonckheere et al. (submitted) ${ }^{1}$ have tested the fractal dimension as a correction parameter for the deviation of forest canopies from assumed theoretical foliage distributions and improved the goodness of fit with more than $10 \%$.

\subsection{Scenario analysis: comparison of the water use of agri-} cultural crops and forest stands in Flanders

ET time series from model simulations of forests and agricultural crops were compared using the Profile Analysis (PA) module in the SAS-software (SAS Institute Inc. 1992). PA with repeated measurements (Johnson and Wichern, 1992; Jobson, 1992) is a statistical method that compares the $E T$ of different groups $g$ (forest and agricultural species) subject

\footnotetext{
${ }^{1}$ Jonckheere, I., Nackaerts, K., van Aardt, J., Muys, B., and Coppin, P.: The relevance of fractal dimension for foliage distribution quantification in forest canopies: a model approach, Ecol. Model., submitted, 2005.
} 
to the same set of $p$ measurements ( 30 years) by examining the $p-1$ slopes between the adjacent coordinate values for the mean vectors of the groups. The null hypothesis $\mathrm{H}_{0}$ is that the population mean profiles are similar. If the $g$ profiles are horizontal there are no condition effects, whereas if the $g$ profiles are equal there are no group effects. If the $g$ profiles are neither horizontal nor equal they still may be parallel, which is an indication that there is no interaction between the group effects and the condition effects. So, first the test of parallel profiles was conducted, followed by the test of equal profiles and finally the profiles were tested whether they were horizontal. It is important to note that a metaanalysis of simulated data and not of observed measurements was performed.

For the derivation of the water use of agriculture and forested land ten agricultural fields (Lolium perenne L., Triticum aestivum L., Hordeum vulgare L., Zea mays L., Beta vulgaris L., each twice) fields with crops on which the WAVE model was calibrated and validated (Vanclooster et al., 1995; Ducheyne et al., 2001; Timmerman et al., 2001) and a selection of 10 forest stands from the calibration and validation exercise (see Sect. 2.3: pine on plot $1 \& 14$, poplar on plot $3 \& 11$, oak on plot $8 \& 10$, beech on plot $7 \& 12$, beech/oak on plot $4 \& 5$ ) were selected. The choice of the forest plots was based on having both calibration and validation sites (except for the mixed beech/oak site).

Concerning the agricultural plots, two crops (a main crop followed by a green cover crop) were considered for each simulation year: wheat, barley, maize and sugar beet, respectively. Pasture was assumed to cover the plot permanently. The fields are located between $51^{\circ} 10^{\prime} 00^{\prime \prime}-50^{\circ} 49^{\prime} 30^{\prime \prime} \mathrm{N}$ and $3^{\circ} 47^{\prime} 30^{\prime \prime}-5^{\circ} 28^{\prime} 30^{\prime \prime} \mathrm{E}$ at a height above sea level between 20 and $100 \mathrm{~m}$ on Podzol (Plot $2 \& 8$ ), Podzoluvisol (Plot 10), Luvisol (Plot 3, 4, 5, 6, 7, 9) and Anthrosol (Plot 1) soils (see also Fig. 4). The main crops wheat and barley were followed by white mustard (Sinapis alba L.), whereas maize was cultivated in combination with grass and sugar beet was followed by fallow land. This means that annual simulation values were the result of two crops, except for pasture. Characteristics of agricultural crops can be found in van Keulen et al. (1982), Penning de Vries and Van Laar (1982), Spitters (1986), Spitters et al. (1986, 1988), among others. Canopy interception was not taken in consideration for agricultural crops since it only represents a small fraction of the total water use. According to White (1999) the canopy interception amounts $3-10 \%$ of the total rainfall, against $18-30 \%$ for forests (Dolman et al., 1998, 2000). Kang et al. (2005) reported a canopy interception of $1.3 \%$ with respect to the total irrigation amount for winter wheat in Beijing. Zhao et al. (2004) assumes that the water interception for alfalfa is close to zero.

To compare the $W U$ of agricultural crops and forest vegetation the same atmospheric conditions were considered for all plots in using the climate data of the Ukkel meteorological station $\left(50^{\circ} 51^{\prime} 00^{\prime \prime} \mathrm{N}, 4^{\circ} 20^{\prime} 00^{\prime \prime} \mathrm{E}, 100 \mathrm{~m}\right.$ above sea level), being the main meteorological station of the Royal Meteorological Institute of Belgium. 30 years of meteorological data, 1971-2000, were selected to be sure that the climate time series encompassed the complete temporal variation of Flanders climate. In summary the WAVE model for each plot was run for a 30-year period using the same climate data, and site specific crop, soil and bottom boundary conditions. The most common lower boundary condition was the representation of a groundwater table near the soil surface (maximally $2 \mathrm{~m}$ below the soil surface) and a very deep groundwater table (free drainage condition). Since long time series of groundwater levels were rarely available, time series of groundwater levels were generated using the physically based autoregressive exogenous variable model (ARX) developed by Knotters and Bierkens (2000). This model correlates the fluctuations of the water table to the temporal variation of the rainfall based on short term time series of observed rainfall and water table depth. The calibrated ARX model was then used to generate the time series of the water table depth for the 30-year period using the 30 -year daily rainfall time series as input.

\section{Results and discussion}

\subsection{Model calibration}

A graphical presentation of time series of measured and simulated volumetric $S M C$ at different depths for plot 1 (a calibration plot with pine cover) is depicted in Fig. 2. The simulation statistics of the calibration plots (1-8) are listed in Table 1 (upper section). Most of the plots yielded an acceptable agreement between simulated and observed SMC (see the corresponding values for the statistical criteria). An in-depth analysis of the simulation results of the calibration plots is given in the following, and consists of a discussion of the simulated total soil water depth (depth of the soil profile equipped with TDR sensors, tensiometers or groundwater tubes) followed by the analysis of the simulated water content per soil layer (equipped with TDR sensors).

Considering the whole soil profile, a slight underestimation occurred for plot $2(C D=1.51)$, and a large overestimation for plot $5(C D=4.01)$. The presence of a heavy clay layer (67\% of the soil particles smaller than $2 \mu \mathrm{m}$ ) at a depth of $55 \mathrm{~cm}$ negatively affected the TDR readings. Previous is reflected in the high $C D$ values (peak values are not well represented). The other soil layers were accurately simulated. Unrealistic TDR readings (SMC larger and smaller than the saturated and residual volumetric $S M C$ ) are responsible for the high $C D$ values in plots 2 and 3 .

Concerning the $M E$ statistics all calibration plots were simulated satisfactorily except for some soil layers in plots 1 , 6, 7 and 8. The negative $M E$ values in Table 1 are frequently observed in the deeper layers. To explain this, four possible reasons are mentioned for plot $1,6,7,8$ but also for the validation plots 2, 9, 11, 12, 13 and 14. The combination of 


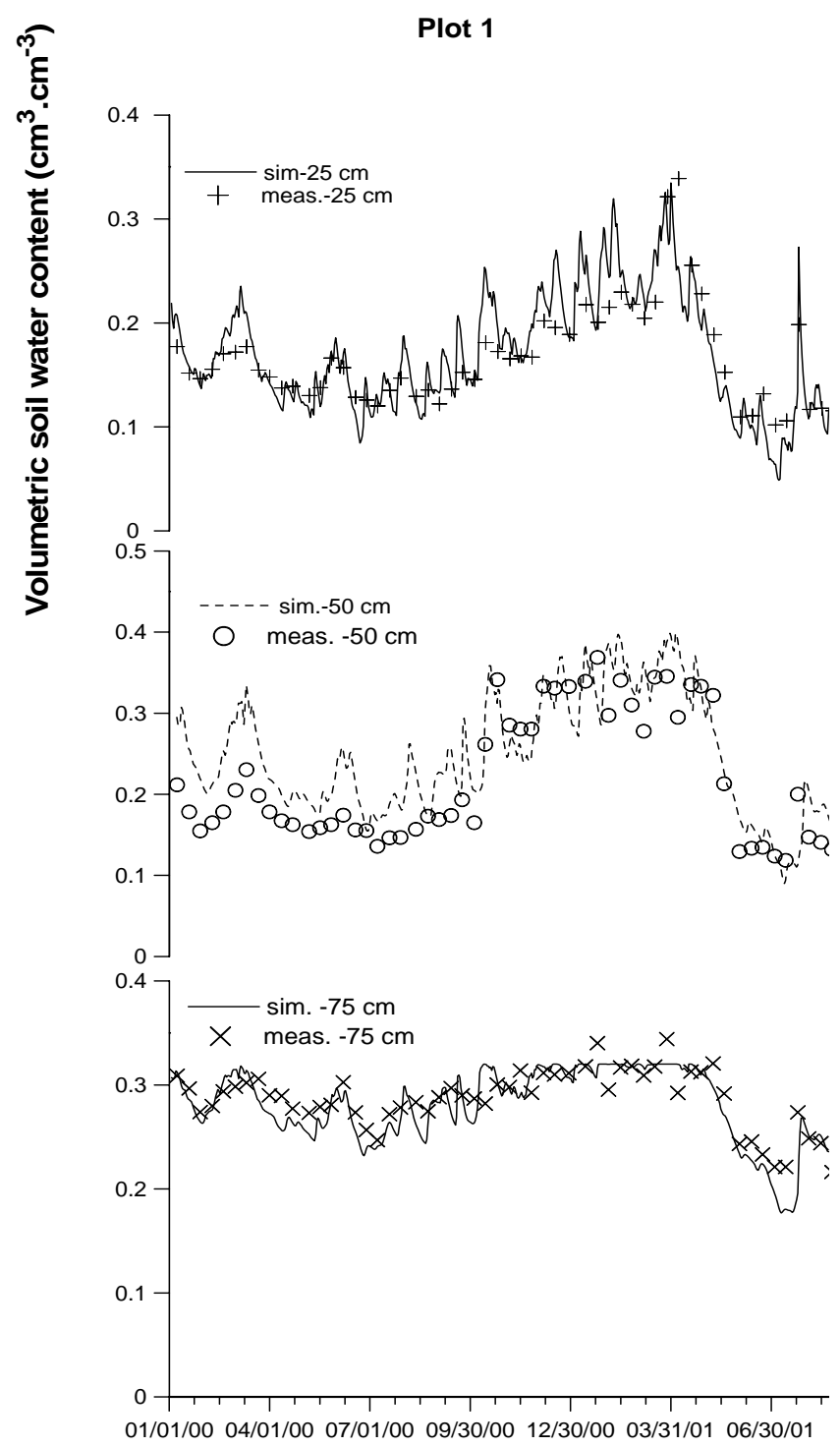

Date $(\mathrm{mm} / \mathrm{dd} / \mathrm{yy})$

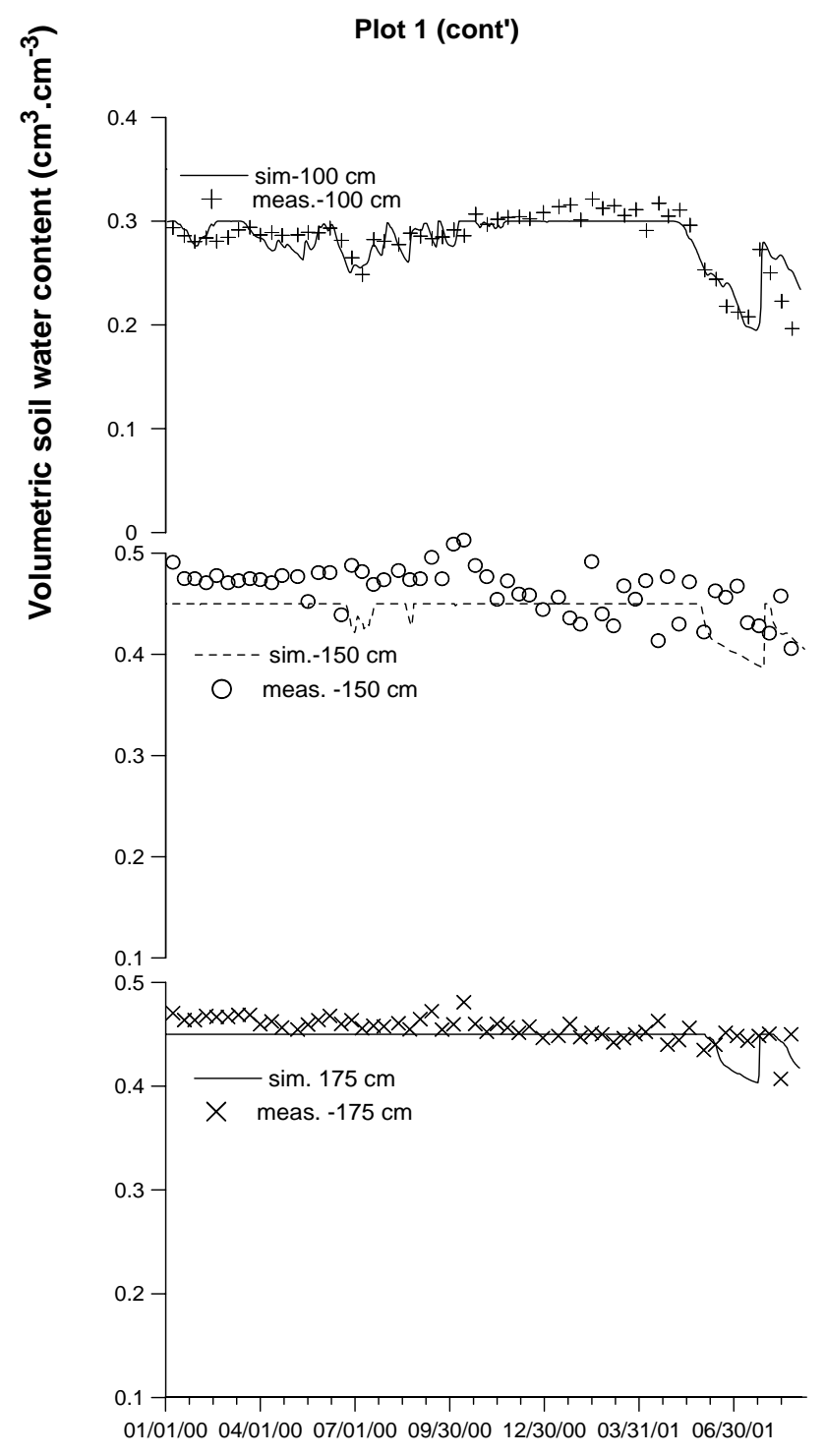

Date $(\mathrm{mm} / \mathrm{dd} / \mathrm{yy})$

Fig. 2. Measured and simulated soil water contents at different depths in the soil profile of plot 1 .

hydrological characteristics and the used statistical measure is involved. Firstly, $S M C$ time series in deeper soil layers (especially when shallow ground water tables are involved) are less sensitive to seasonal variations than $S M C$ time series in the near surface layers. Hence, the individual observed $S M C$ values $\left(O_{i}\right)$ are nearly constant (horizontal line) - as is illustrated for plot 1 at $175 \mathrm{~cm}$ depth in Fig. 2 - and $O_{i}$ values are nearly equal to the averaged observed value $(\bar{O})$. Since the summed squared differences between $O_{i}$ and $\bar{O}$ are very small, the ratio in Eq. (9) is large and result in negative $M E$ values. The second reason might be measurements errors of observed $S M C$ values in soil layers with a static $S M C$ behaviour (plot 11,13). The $S M C$ values vary around $\bar{O}$, while the $P_{i}$ values do not change much over time. If the averaged predicted $S M C$ is slightly larger than $\bar{O}$, negative $M E$ values are obtained. A third reason might be the occurrence of very high short term $S M C$ variations (due to rainfall and soil evaporation) near the surface layer (plot 14) not well captured by the model. Finally, if the modelled water uptake by roots is underestimated, the averaged $P_{i}$ values tend to be larger than $\bar{O}$. This results again in negative $M E$ figures.

The RMSE for the profiles is acceptable with values smaller than 2.00, except for plot 4 . Plots 4 and 5 are good examples to illustrate why multi-criteria statistics should be used. The $C D$ of plot 4 indicates good simulation results, while the $M E$ suggests that peaks are not well represented by the model. The RMSE is rather large taking into account that the change in $S M C$ between summer and winter is maximal 
$0.10 \mathrm{~cm}^{3} \mathrm{~cm}^{-3}$. For plot 5 the $C D$ is indicating that the measured values are much higher than the simulated ones. The groundwater table is located at less than $70 \mathrm{~cm}$ below surface for the whole year. Therefore very little variation in $S M C$ is observed and the $C D$ values become large.

In plot 1 (see also Fig. 2) very low RMSE's were observed in contrast to the high changes in $S M C$ (more than $0.15 \mathrm{~cm}^{3} \mathrm{~cm}^{-3}$ between summer and winter at $25,50,75$ and $100 \mathrm{~cm}$ depth). The $M E$ of the above mentioned soil layers is very good, indicating that most observed peaks are well simulated. Below $100 \mathrm{~cm}, M E$ indicates an unacceptable result notwithstanding that the soil water profile is in general well simulated. The $C D$ value at $100 \mathrm{~cm}$ indicates model underestimations, meaning that the simulated water extraction from this soil layer is too low. Keeping in mind the large changes of $S M C$ of 0.10 to $0.30 \mathrm{~cm}^{3} \mathrm{~cm}^{-3}$, the $R M S E$ value of plot 3 is acceptable. The $M E$ at the different soil depths indicates a representative simulation of the peaks in soil water content, whereas the $C D$ indicates that the model significantly underestimates the average course of soil water content.

\subsection{Model validation}

In Table 1 (bottom section) the range of the statistics of the measured and simulated volumetric SMC of the soil profile, as derived for different depths of the soil profile of the validation plots (9 to 14) are given. The SMC of the beech stands in plots 9 and 12 were simulated using the calibrated values of plot 7. The whole soil profile of plot 9 was well simulated, in contrast to the water content at 96 and $128 \mathrm{~cm}$ depth ( $R M S E=7.86$ and 3.56; $M E=-0.42$ and -9.50 , respectively). At a depth of $96 \mathrm{~cm}$ the $C D$ values 2.85 , indicating an overestimation of the modelled SMC (thus, the observed SMC over the specific period is lower). It might be due to the effect of the presence of fine roots in this layer of which the effect was incorrectly mimicked with the WAVE model. The underestimation of the modelled SMC in the layer below $(128 \mathrm{~cm})$ is most likely the consequence of overemphasizing in WAVE the effect of the thin clay layer, $3 \mathrm{~cm}$ in thickness, on top of this layer. The layer restricts the redistribution of the excess infiltration water, resulting in an underestimation of the modelled $S M C$ beneath the restricting thin layer.

The beech stand of plot 12 illustrates poor statistics (especially $M E$ ) at 15,65 and $140 \mathrm{~cm}$ depth. This plot is a well drained loamy soil characterized by thin fingered soil layers. This hampered seriously the collection of representative undisturbed soil cores for the measurement in the laboratory of the soil hydraulic properties. Moreover, due to the overall dry conditions of the soil profile determination of the bottom boundary condition with tensiometers was inaccurate. On the other hand, at plot 12, water content changes larger than $0.15 \mathrm{~cm}^{3} \mathrm{~cm}^{-3}$ were observed at 5,15 and $25 \mathrm{~cm}$ soil depths, being responsible for a profile RMSE of 2.78. Problems however did appear in constructing an accurate water extraction function for the root system.
The oak forest of plot 10 was simulated using the calibration results of plot 8 . Again model underestimation is observed. The RMSE of 4.02 is acceptable because of the observed water content changes over the season of $0.30 \mathrm{~cm}^{3} \mathrm{~cm}^{-3}$. Model underestimation may result from lateral water flows, since this plot is located in a former swamp. The drainage to the catchment of the Scheldt River is man controlled. Sudden drainage of water may occur, lowering the SMC. Especially, during the growing season, when the water demand for evapotranspiration is large, the WAVE model is simulating less water extraction than observed.

The poplar stand of plot 3 was validated using the parameters derived for plot 11. Again, the occurrence of a clay layer, situated at a depth of $120 \mathrm{~cm}$, hindered seriously the interpretation of the TDR readings. TDR readings above saturated and below residual soil moisture levels were observed, despite the shallow water table. The calibration values of plots 1 and 2 were validated using plots 13 and 14 . The results of plot 14 are acceptable, despite the poor $M E$ values. Apart from the simulations at a soil depth of $3 \mathrm{~cm}$ very few changes in $S M C$ are observed (less than $0.1 \mathrm{~cm}^{3} \mathrm{~cm}^{-3}$ ) at larger depths. The surface layer of plot 14 is very thin with a high organic matter content $(4.7 \%)$, affecting significantly the TDR readings. The poor $M E$ is the result from simulated small peak values, which were not recorded. The high iron content of the soil in plot 13 is very likely responsible for the poor TDR readings. Gravimetric cross-calibration at 6 moments in time of the TDR readings did not improve the reliability of the readings. The RMSE values are better because of the low level of observed soil water dynamics.

\subsection{Water balance in relation to forest stand characteristics}

\subsubsection{PAI}

Table 2 summarizes the stand characteristics of the calibration and validation plots: minimum and maximum $P A I, T F$ and $S F$ coefficients for the winter and summer season, minimum and maximum $K_{c}$, and the average ratio between the actual and potential crop evapotranspiration $E T_{\text {act }} / E T_{c}$, for the period 2000-2001, respectively.

Maximum $P A I$ values $\left(\mathrm{m}^{2} \mathrm{~m}^{-2}\right)$ vary between 1.80 (pine) and 5.50 (ash); minimum values between 0.10 (beech) and $2.60\left(\mathrm{~m}^{2} \mathrm{~m}^{-2}\right)$ (pine). As a consequence of the evergreen character, little variation in $P A I$ values is found for the pine stands. The mixed stands show higher peak variations in PAI. In comparison to our results, Dolman et al. $(1998,2000)$ report higher maximal $L A I$ values for pine and mixed broadleaf forests (respectively 1.90 and 3.80). Probably this is both due to different stand characteristics (stand age, tree density, and site quality) and a different $L A I$ determination method (PAI includes stems and branches). The ratios of the original $P A I$ over the corrected $P A I$ for clusters are $0.56,0.54,0.56,0.58$, $0.57,0.54,0.53,0.57,0.59$ and 0.59 for plot 1 to 10 . For poplar Dolman et al. $(1998,2000)$ reported 3.70 , which is 
Table 2. Stand characteristics of the calibration and validation plots: minimum and maximum Plant-Area-Index (PAI); throughfall and stemflow $(T F \& S F)$ coefficients for the winter and summer season, respectively; minimum and maximum crop coefficient $\left(K_{C}\right)$; and the average ratio of the actual over the potential evapotranspiration $\left(E T_{\text {act }} / E T_{c}\right.$ average $)$, for the period 2000-2001.

\begin{tabular}{|c|c|c|c|c|c|c|c|c|c|}
\hline Parameter & units & $\begin{array}{c}\text { Calibration plot } \\
1 \\
\text { Pinus sylvestris }\end{array}$ & 2 & $\begin{array}{c}3 \\
\text { Populus }\end{array}$ & $\begin{array}{c}4 \\
\text { Fagus sylvatica } \\
\text { Quercus robur }\end{array}$ & $\begin{array}{c}5 \\
\text { Fagus sylvatica } \\
\text { Quercus robur }\end{array}$ & $\begin{array}{c}6 \\
\text { Fraxinus excelsior }\end{array}$ & $\begin{array}{c}7 \\
\text { Fagus sylvatica }\end{array}$ & $\begin{array}{c}8 \\
\text { Quercus robur }\end{array}$ \\
\hline$P A I_{\max }$ & $\left(\mathrm{m}^{2} \mathrm{~m}^{-2}\right)$ & 1.80 & 1.80 & 4.80 & 5.46 & 5.46 & 5.50 & 4.67 & 3.50 \\
\hline$P A I_{\min }$ & $\left(\mathrm{m}^{2} \mathrm{~m}^{-2}\right)$ & 1.30 & 1.30 & 1.50 & 1.00 & 1.00 & 1.02 & 1.77 & 2.50 \\
\hline$T F \& S F_{\text {winter }}$ & $(-)$ & 0.041 & 0.041 & 0.136 & 0.129 & 0.129 & 0.605 & 0.797 & 0.611 \\
\hline$T F \& S F_{\text {summer }}$ & $(-)$ & 0.062 & 0.062 & I & 0.207 & 0.207 & 0.901 & 0.972 & 0.818 \\
\hline$K_{c \max }(*)$ & $(-)$ & 0.97 & 0.97 & 1.10 & 0.95 & 0.95 & 0.85 & 0.90 & 0.86 \\
\hline$K_{c \min }(*)$ & $(-)$ & 0.71 & 0.71 & 0.90 & 0.45 & 0.45 & 0.70 & 0.78 & 0.75 \\
\hline \multirow{2}{*}{$E T_{\text {act }} / E T_{c}$ average } & $(\%)$ & 96.2 & 89.2 & 97.4 & 99.6 & 95.4 & 91.6 & 95.4 & 77.6 \\
\hline & & Validation plots & & & & & & & \\
\hline \multirow[t]{2}{*}{ Parameter } & units & 9 & 10 & 11 & 12 & 13 & 14 & & \\
\hline & & Fagus sylvatica & Quercus robur & Populus sp. & Fagus sylvatica & Pinus sylvestris & Pinus nigra & & \\
\hline$P A I_{\max }$ & $\left(\mathrm{m}^{2} \mathrm{~m}^{-2}\right)$ & 4.00 & 4.02 & 4.10 & 3.65 & 2.14 & 3.20 & & \\
\hline$P A I_{\min }$ & $\left(\mathrm{m}^{2} \mathrm{~m}^{-2}\right)$ & 0.10 & 2.00 & 2.00 & 2.00 & 1.92 & 2.60 & & \\
\hline$T F \& S F_{\text {winter }}$ & $(-)$ & 0.860 & 0.780 & 0.629 & 0.737 & 0.625 & 0.768 & & \\
\hline$T F \& S F_{\text {summer }}$ & $(-)$ & 0.920 & 0.970 & 0.856 & 0.934 & 0.906 & 0.835 & & \\
\hline$K_{c \max }(*)$ & $(-)$ & 0.90 & 0.86 & 1.10 & 0.90 & 0.97 & 0.97 & & \\
\hline$K_{c \min }(*)$ & $(-)$ & 0.78 & 0.75 & 0.90 & 0.78 & 0.71 & 0.71 & & \\
\hline$E T_{\text {act }} / E T_{c}$ average & $(\%)$ & 98.9 & 95.3 & 97.5 & 95.6 & 98.1 & 92.8 & & \\
\hline
\end{tabular}

(*) Reference surface is grass (Doorenbos and Pruitt, 1977)

smaller than 4.80 at plot 3 . Plot 3 was the only forest stand where the $L A I$ was not determined using digital hemispherical imagery. Instead, net radiation inside and outside the forest stand was measured (Meiresonne et al., 1999). For plots 9 and 10, Samson (2001) cited an upper $L A I$ value of 4.35. In uniform stands of ash, oak and beech, Samson et al. (1997) reported $L A I$ values of $2.49,4.37$ and 5.87.

\subsubsection{Crop factor}

The $K_{c}$ of trees, apart from poplar, is generally less than one. This is in contrast to values reported by Doorenbos and Pruitt (1977) for full grown agricultural crops as barley $\left(K_{c}=1.1\right)$, wheat (1.1), sugar beet (1.1), maize (1.15) in similar climatologic conditions, but under optimum soil water, management and environmental conditions. Fruit trees have maximum $K_{c}$ values between 0.95 and 1.2 and minimum $K_{c}$ values between 0.40 and 0.80 as reported by Allen et al. (1998). Meiresonne et al. (2003) gave minimum and maximum $K_{c}$ values for Scots pine between 0.70, whereas this study yielded values between 0.71 and 0.97 . However, Hupet and Vanclooster (2004) commented the $E T_{c}\left(K_{c} . E T_{0}\right)$ derived by Meiresonne et al. (2003) and explained why $E T_{c}$ was overestimated. Schaap et al. (1997) cited crop factors of 0.75 before bud break to 1.0 after shoot extension implemented for a Douglas fir forest in the centre of the Netherlands. Edraki et al. (2004) reported crop factors of 0.79 for Rhodos grass and 0.85 for Eucalypt (calculated with pan evapotranspiration) in Australia, values which were found statistically not different $(0.95 \%)$. Forests seem to consume more water, which may indicate that trees have more impact on groundwater tables than crops (Dolman et al., 1998, 2000).

\subsubsection{Root water uptake}

The vertical distribution of the semi-empirical root water uptake function, $\alpha(h) \cdot S_{\max }(z)$, was evaluated comparing for each soil layer the modelled with observed SMC time series. This macroscopic sink term approach was recently used for instance by Homaee et al. (2002a, b). An illustration of the non-linear release of soil water due to plant water uptake was given by Warren et al. (2005). They studied the vertical distribution of soil water storage and release dynamics in Pacific Northwest coniferous forests. $40-60 \%$ of the fine roots were located in the upper $20 \mathrm{~cm}$ of the soil. However, the soil layer only accounted for $20 \%$ of the total water depletion from the upper $2 \mathrm{~m}$ at peak uptake, declining to $4-6 \%$ later in the season. This illustrates the contribution of deeper roots to water uptake. Nevertheless, Warren et al. (2005) pointed out that the water uptake from the entire $2 \mathrm{~m}$ soil profile strongly depends on the water potential at $20 \mathrm{~cm}$ which is an indication that fine roots in the upper soil may play an important role in regulating water uptake. Brauda et al. (2005) compared different root uptake models and found out that the $S M C$ in deeper soil layers $(1 \mathrm{~m})$ was simulated with close to zero and negative $M E$ values. In this study on some calibration and validation plots similar less optimal $M E$ values in deeper soil 
Table 3. Water balance data in mm (rainfall, actual transpiration $\left(T_{\text {act }}\right)$, actual soil evaporation $\left(E_{\text {act }}\right)$ and canopy interception evaporation (INT)) of the calibration and validation plots for the year 2000 and the period January-August of 2001.

\begin{tabular}{|c|c|c|c|c|c|c|c|c|c|}
\hline \multirow[b]{3}{*}{ Year } & \multirow[b]{3}{*}{ Parameter (mm) } & \multicolumn{8}{|l|}{ Calibration plots } \\
\hline & & 1 & 2 & 3 & 4 & 5 & $6^{* *}$ & 7 & 8 \\
\hline & & Pinus sylvestris & Pinus sylvestris & Populus & $\begin{array}{c}\text { Fagus sylvatica } \\
\text { Quercus robur }\end{array}$ & $\begin{array}{l}\text { Fagus sylvatica } \\
\text { Quercus robur }\end{array}$ & Fraxinus excelsior & Fagus sylvatica & Quercus robur \\
\hline \multirow[t]{4}{*}{2000} & Rainfall & 887.5 & 887.5 & 773.4 & 773.4 & 773.4 & 399.9 & 836.5 & 756.6 \\
\hline & $T_{\mathrm{act}}$ & 223.7 & 171.5 & 407.2 & 271.5 & 264.4 & 119.5 & 358.4 & 317.4 \\
\hline & $E_{\text {act }}$ & 152.6 & 91.2 & 98.9 & 34.5 & 45.8 & 4.6 & 49.4 & 46.3 \\
\hline & $I N T$ & 52.8 & 52.8 & 105.0 & 122.8 & 122.7 & 47.5 & 88.6 & 123.3 \\
\hline \multirow[t]{4}{*}{$2001 *$} & Rainfall & 577.3 & 577.3 & 540.1 & 540.1 & 540.1 & 595.5 & 595.3 & 694.5 \\
\hline & $T_{\text {act }}$ & 222.7 & 184.8 & 401.6 & 224.5 & 198.1 & 198.0 & 287.4 & 339.3 \\
\hline & $E_{\text {act }}$ & 150.0 & 61.7 & 73.8 & 13.6 & 15.5 & 2.3 & 62.0 & 27.1 \\
\hline & $I N T$ & 52.1 & 52.0 & 94.7 & 165.4 & 165.3 & 184.7 & 69.7 & 105.8 \\
\hline & & \multicolumn{8}{|l|}{ Validation plots } \\
\hline & & $9 * * *$ & $10 * * *$ & $11^{* * *}$ & $12 * * *$ & $13^{* * *}$ & $14 * * *$ & & \\
\hline Year & Parameter (mm) & Fagus sylvatica & Quercus robur & Populus sp. & Fagus sylvatica & Pinus sylvestris & Pinus nigra & & \\
\hline \multirow[t]{4}{*}{2000} & Rainfall & 654.3 & 971.7 & 817.9 & 836.5 & 826.4 & 711.2 & & \\
\hline & $T_{\text {act }}$ & 369.7 & 338.5 & 347.8 & 358.4 & 303.2 & 265.8 & & \\
\hline & $E_{\text {act }}$ & 80.6 & 23.9 & 54.5 & 49.4 & 80.2 & 18.6 & & \\
\hline & $I N T$ & 64.9 & 109.0 & 207.5 & 88.6 & 91.7 & 265.8 & & \\
\hline \multirow[t]{4}{*}{$2001 *$} & Rainfall & 595.3 & 624.7 & 693 & 595.3 & 672.1 & 644.3 & & \\
\hline & $T_{\mathrm{act}}$ & 287.4 & 466.0 & 306.1 & 287.4 & 153.7 & 229.1 & & \\
\hline & $E_{\text {act }}$ & 62.0 & 64.2 & 38.0 & 62.0 & 36.6 & 10.1 & & \\
\hline & $I N T$ & 69.7 & 79.7 & 223.0 & 69.7 & 215.3 & 139.5 & & \\
\hline
\end{tabular}

* January-August 2001 only

* August-September 2000

** March-December 2000

layers were found. Coners and Leuschner (2005) observed a very high temporal and spatial heterogeneity of root water uptake which could be caused by contrasting and variable hydraulic properties of individual roots or root segments. Coefficients of variation ranged between $25 \%$ and $150 \%$ for $4-6$ roots of a species in a soil horizon. Errors in the water up take function of $17 \%$ in a corn field in Portugal (observed versus simulated values) were reported by Cameira et al. (2005). Although the dynamics of root systems of large trees are difficult to assess. Techniques such as ground-penetrating radar combined with sap flow measurements performed on individual root branches may assess the water uptake as illustrated by Nadezhdina and Cermák (2003).

\subsubsection{Water use components $\left(E T_{\text {act }}, T_{\text {act }}, E_{\text {act }}, I N T\right)$}

The ratio $E T_{\text {act }}$ to $E T_{c}$ varies from 77.6 to $99.6 \%$ for the calibration plots and from 92.8 to $98.9 \%$ for the validation plots. For oak forests, Cermák et al. (1982) and Nizinski et al. (1989) found a transpiration ratio of $80 \%$. Ladekarl (1998) found a ratio of $90 \%$, corresponding well with the values listed in Table 2.

The water balance data of the calibration and validation plots for 2000 and part of 2001 (Rainfall, $T_{\text {act }}, E_{\text {act }}$ and INT) are given in Table 3.
The ratios INT/Rainfall, $E_{\text {act }} /$ Rainfall and $T_{\text {act }} /$ Rainfall of the calibration plots range between 5.9-31.0\%, 0.4-26.0\%, $19.3-74.4 \%$, respectively. For the validation plots the ratios are between $9.9-37.4 \%, 1.6-12.3 \%$ and $22.9-74.6 \%$. Average values for INT/Rainfall are $22 \%$ in the growing season and $14 \%$ in the dormant season. Dolman et al. $(1998,2000)$ report for a poplar, a pine and a mixed broadleaf forest in similar climatologically conditions a ratio of INT/Rainfall of 18, 27 and 30\%. Mixed forests have interception losses of 24-30\% (Dolman et al., 1998, 2000).

Annual transpiration values of $407.2 \mathrm{~mm}$ for poplar, $317.4 \mathrm{~mm}$ for oak, $171.5-223.7 \mathrm{~mm}$ for pine, $358.4 \mathrm{~mm}$ for beech and $264.4-271.4 \mathrm{~mm}$ for beech/oak were modelled with WAVE using in situ measurements gathered in the period 2000-2001 (Verstraeten et al., 2001). These values are in the same range as those reported by Dolman et al. (1998, 2000).

For the seasonal $T_{\text {act }}$ of different uniform forests (oakbeech and ash), calculated from basal sap flow density measurements using $L A I$ as a scaling factor, Samson (2001) reports annual values of 376 and $188 \mathrm{~mm}$, respectively. This author also cites Peck and Mayer (1996) who concluded a mean annual $T_{\text {act }}$ of $363 \mathrm{~mm}$ based on data of evaporation studies in 9 European beech forests. Meiresonne et al. (1999) found by applying the WAVE model a seasonal 


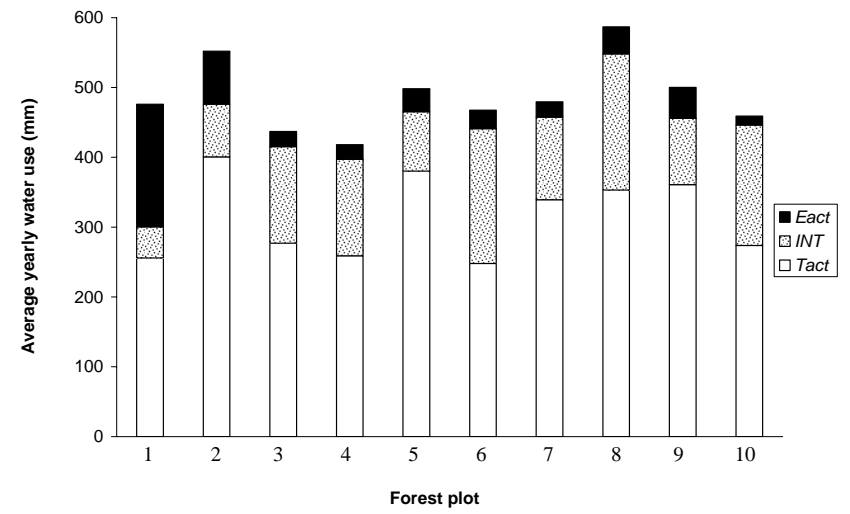

Fig. 3. Average yearly water use components of 10 forest stands in Flanders. $E T_{\text {act }}$ is the sum of $T_{\text {act }}, E_{\text {act }}$ and $I N T$ (period: $1971-$ 2000).

$T_{\text {act }}$ of $311 \mathrm{~mm}$ for a mature hybrid poplar stand. A Scots pine stand showed a higher annual $T_{\text {act }}$ when the growing season was dry and warm $(295 \mathrm{~mm})$ in comparison with a wet and cold summer (226 mm) (Meiresonne et al., 2003).

Larcher (1995) reported interception losses in temperate zone deciduous woodland typically ranging between 15 and $30 \%$ of the precipitation. If the interception losses are calculated as a percentage of the total $W U$, values of $18.5 \%$ for the poplar stand (plot 3 ) and $29.1 \%$ for the pine stand (plot 1) are found. These values are acceptable with a maximum $L A I$ of 1.8 for plot 1 .

For the pine stand (plot 1) the contributions of $T_{\text {act }}, I N T$ and $E_{\text {act }}$ in the total $W U$ for dry months (rainfall of 61.8$51.8 \mathrm{~mm}$ ) with high $E T_{c}$ demand (96-90 mm) in 2000 (June) and 2001 (June) are respectively 53,12 and 35\% for June 2000 and respectively 54,11 and $36 \%$ for June 2001 . If the monthly $E T_{c}$ is low (7 and $8 \mathrm{~mm}$ in January 2000 and 2001) the $I N T / E T_{\text {act }}$ ratio varies between 88 and $98 \%$. For the poplar stand (plot 3 ) for dry months (rainfall amount of 26 and $43 \mathrm{~mm}$ ) and high $E T_{c}$ demand (109 and $119 \mathrm{~mm}$ ), e.g. August 2000 and June 2001, the contributions of the $T_{\text {act }}, I N T$ and $E_{\text {act }}$ is 91 and 84, 3-8 and 6-9\%, respectively. Schaap et al. (1997) reported an average contribution of $E_{\text {act }}$ of $11 \%$ (range: $7-13 \%$ ) in a Dutch Douglas fir forest. If the monthly $E T_{c}$ is low (6 and $14 \mathrm{~mm}$ in January 2000 and $2001)$ the $I N T / E T_{\text {act }}$ ratio becomes $97-81 \%$. With a water use of $567 \mathrm{~mm}$ for plot 3 in 2000 , the $E T_{\text {act }}$ of poplar stand was considerably larger than the evaporative water loss of the pine stand of plot $1(471 \mathrm{~mm})$.

Sap flow measurements carried out on plots 1, 2 and 3 in the period 28 May-15 September 2000, using the sensors developed by Cermák and Nadezhdina (1998), resulted in $T_{\text {act }}$ values of 132, 113 and $201 \mathrm{~mm}$, respectively (Verstraeten et al., 2001). WAVE simulations for $T_{\text {act }}$ for the same plots and period were 136, 111 and $280 \mathrm{~mm}$. For plot 1 and 2 both methods yielded similar values, in contrast to plot 3 . A possible explanation could be that the contribution of $E_{\text {act }}$ in plot

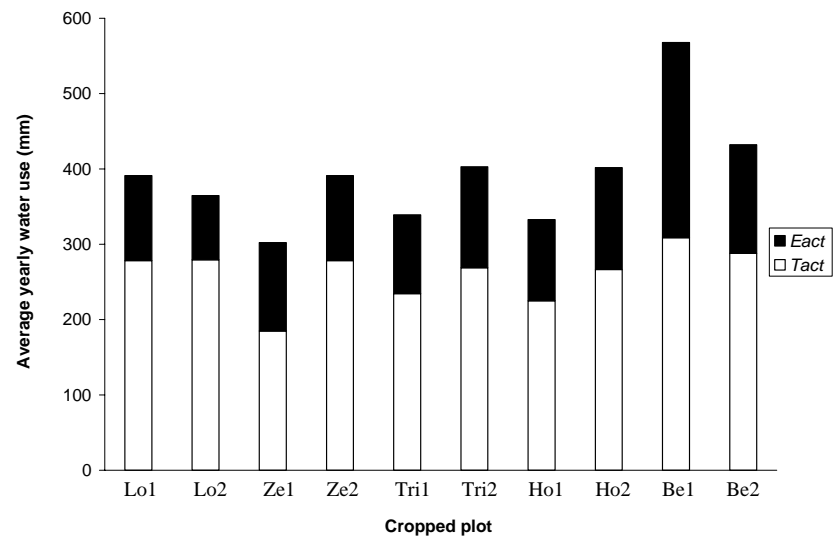

Fig. 4. Averaged yearly water use components of 10 agricultural fields in Flanders (Lolium perenne L.: Lo; Triticim aestivum L.: Tri; Zea mays L.: Ze; Hordeum vulgare L.: Ho and Beta vulgaris L.: , Be). $E T_{\text {act }}$ is the sum of $T_{\text {act }}$ and $E_{\text {act }}$ (period: 1971-2000).

3 in the total $W U$ is too small compared to the $T_{\text {act }}$ because of the high $L A I$ of the forest stand in this plot. On the other hand, in order to obtain modelled $T_{\text {act }}$ values which are similar to the measured using sap flow sensors, the $L A I$ must be smaller than 3. Meiresonne et al. (1999) carried out sap flow measurements in plot 3 in the period 8 August-3 September 1997, and found at maximal developed LAI a correlation between the transpiration measured with sap flow $\left(T_{\text {sapfl }}\right)$ and $E T_{c}$ of $T_{\text {sapfl }}=0.86 \times E T_{c}$ with a correlation coefficient of 0.77 . The same correlation was derived when the simulated $T_{\text {act }}$ was plotted against $E T_{c}$ for the period 1 July-31 August 2000 with a correlation coefficient of 0.78 . If these correlations are applied, the underestimation of the measured sap flow versus the simulated transpiration in 2000 is probably due to up-scaling errors.

\subsection{Scenario analysis}

The annual $W U$ components for each plot averaged over 30years are depicted in Fig. 3 for forests and Fig. 4 for agricultural crops. Notice that the same species can have different $W U$ amounts despite the same atmospheric conditions. This is due to different soil and environmental characteristics. Stand characteristics can be highly variable for the same tree species as shown in Table 3. PAI, TF and $S F$ are stand-specific in contrast to crops, which are much more uniform. $T_{\text {act }}$ values of the forests vary between 248.1 and $400.5 \mathrm{~mm}, I N T$ values between 44.5 and $195.3 \mathrm{~mm}$ and $E_{\text {act }}$ values between 12.8 and $175.6 \mathrm{~mm}$. The average yearly rainfall amount is $819.2 \mathrm{~mm}$. The ratio of these values to rainfall is comparable with reported ones. For agricultural vegetation, WAVE simulated averaged $T_{\text {act }}$ values between 184.7 and $287.8 \mathrm{~mm}$ and $E_{\text {act }}$ values between 85.3 and $259.2 \mathrm{~mm}$.

For the period 1997-2000, the $W U$ values of respectively 10 forest and 10 agricultural plots were averaged (see Fig. 5). 


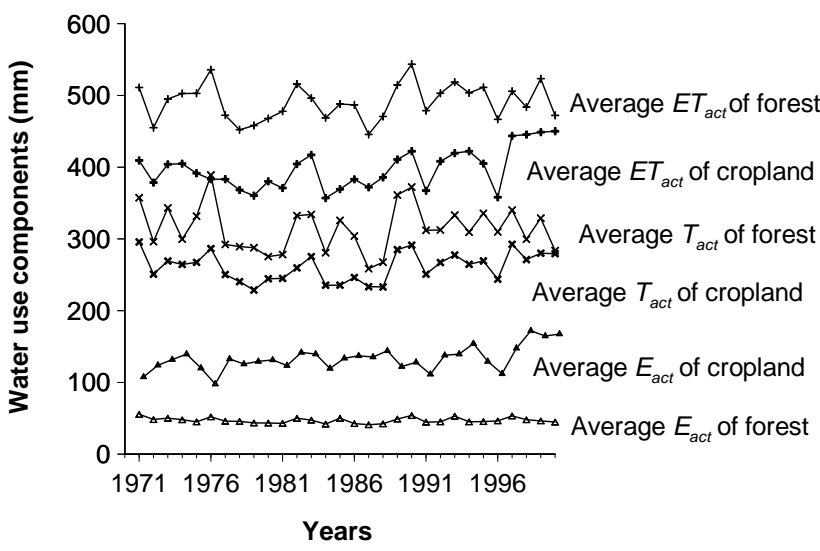

Fig. 5. Yearly variation of the actual evapotranspiration, crop transpiration and soil evaporation, averaged for 10 forest stands and 10 agricultural fields in Flanders, for the simulation period 1971-2000.

The $E T_{\text {act }}$ and $T_{\text {act }}$ time series indicate some evidence of parallelism. However, the time series for forests depict more and sharper peak values while agricultural fields respond less to variations in the atmospheric water demand. From the results of the Multiple Analysis Of Variance (MANOVA) (Profile Analysis method) and the F-statistics it is concluded that the hypothesis "of no land use effect on the $E T_{\text {act }}$ " does not apply in favour of the alternative hypothesis. Clearly, this means that forests show different water use behaviour than agricultural crops. For the sake of completeness one has to be aware that no interception evapotranspiration of the agriculture crops has been taken into account (3-10\%). In addition, the statistical analyses revealed that the assumption "of no overall effect of the different years ( 30 conditions)" is not valid. Again, this means that different years influence the water use. This is consistent with the results obtained with the Mixed General Linear Model method; see Wolfinger and Chang (1995) for more details on the technique. This study clearly shows that the overall water use is higher for forest. This is in concordance with results as reported by Ladekarl (1998), Bosch and Hewlett (1982), but not with results reported as by Bastiaanssen et al. (2001). This might be due to the snapshot sample of water use during summer (maximum crop growth), not integrated on annual basis. Soil evaporation is considerably lower in forests compared to cropland. It is important to note that the results of these analyses were carried out irrespective of the precondition of normality for all time series.

Average $E_{\text {act }}$ distribution of forests and agricultural fields in Flanders is not normally distributed. Additional analysis shows that the distribution is lognormal, primarily due to the extremes observed in plot 1 , a very sparse pine forest ( $P A I_{\max }$ is 1.80 ) with an $E_{\text {act }}$ which is much larger than for the other forest sites (PAI $I_{\max }$ ranges from 3.20 to 5.46). The results of the t-test for the assumption of two distributions having the same variance (homoscedastic), or unequal vari-
Table 4. Average, standard deviation and the 5 and 95 percentiles of the yearly water balance components for an average forest stand and agricultural field, calculated for the period 1971-2000.

\begin{tabular}{ccccccc}
\hline & & $\begin{array}{c}\text { Rainfall } \\
(\mathrm{mm})\end{array}$ & $\begin{array}{c}E T_{\mathrm{act}} \\
(\mathrm{mm})\end{array}$ & $\begin{array}{c}T_{\mathrm{act}} \\
(\mathrm{mm})\end{array}$ & $\begin{array}{c}E_{\mathrm{act}} \\
(\mathrm{mm})\end{array}$ & $\begin{array}{c}I N T \\
(\mathrm{~mm})\end{array}$ \\
\hline \multirow{2}{*}{ Forest } & $\mathrm{N}(0,1)$ & & $\mathrm{H}_{0}$ & $\mathrm{H}_{0}$ & $\mathbf{H}_{a}$ & $\mathrm{H}_{0}$ \\
& mean & 819.2 & 491.0 & 314.8 & 47.1 & 125.6 \\
& $\mathrm{stdev}$ & 123.9 & 56.58 & 57.71 & 48.52 & 51.23 \\
& $0.05 \%$ & & 418.0 & 248.1 & 12.8 & 44.5 \\
& $0.95 \%$ & & 587.6 & 400.5 & 175.6 & 195.3 \\
Agriculture & & & & & & \\
& $\mathrm{N}(0,1)$ & & $\mathrm{H}_{0}$ & $\mathrm{H}_{0}$ & $\mathbf{H}_{a}$ & $/$ \\
& mean & 819.2 & 397.5 & 261.2 & 131.4 & $/$ \\
& stdev & 123.9 & 82.30 & 36.30 & 48.09 & $/$ \\
& $0.05 \%$ & & 302.1 & 184.7 & 85.3 & $/$ \\
& $0.95 \%$ & & 567.9 & 308.7 & 259.2 & $/$
\end{tabular}

$\mathrm{H}_{0}$ null hypothesis

$\mathrm{H}_{a}$ alternative hypothesis

ance show that the assumption of equal means for $E T_{\text {act }}, T_{\text {act }}$ and $E_{\text {act }}$ of forests and agriculture in Flanders is rejected at the $95 \%$ level (Table 4).

\section{Conclusions}

The paper presented the calibration and validation results of the WAVE model applied to temperate lowland forests in Flanders. The water use components of forests and agricultural plots were derived from a 30-year scenario analysis. Manual calibration of the most sensitive parameters of the WAVE model resulted for most plots to acceptable multicriteria statistics. However, the variations in $S M C$ in some validation plots were not accurately simulated mainly due to plot specific factors. Statistical analysis of the simulated and observed $S M C$ at different depths of the soil profile leads to the conclusion that an accurate description of the root water extraction function remains a bottle-neck.

Poplar stands consumed more water than pine stands, but for the latter in contrast to the former the contribution of interception was much smaller. During periods with a high atmospheric water demand (summer) the contribution of the canopy interception evaporation to the total amount of the actual evapotranspiration was lower, while the actual transpiration became a larger fraction of the actual evapotranspiration. Furthermore, it has been shown that the simulated $T_{\text {act }}$ for two plots corresponded well with the results of sap flow measurements.

A central question investigated in this paper was whether or not simulated water use time series of forest and cropland are similar. Based on the results of the Profile Analysis method the assumption that the water use components of forest and agricultural vegetation are equal must be rejected, and the $W U$ components seems to be dependent from 
the atmospheric conditions of the year (wet versus dry years). The study also reveals that the time-land use interaction affects the $W U$ components. The average annual simulated $E T_{\text {act }}$ is $491 \mathrm{~mm}$ for forest stands and $398 \mathrm{~mm}$ for crops; $T_{\text {act }}$ is respectively 315 and $261 \mathrm{~mm}$. The annual $E_{\text {act }}$ under forest vegetation is estimated at $47 \mathrm{~mm}$ and $131 \mathrm{~mm}$ for cropland. The average annual INT in forest is $126 \mathrm{~mm}$. The interception of agriculture crops is assumed to be very small and is set to zero although literature applied values state that interception losses of agricultural crops can vary between 25 and $82 \mathrm{~mm}$.

Although the study yielded a good picture of the ratio between the annual water fluxes in forest stands and cropland, future research should focus on the experimental determination of the different contributing mass fluxes in evapotranspiration, as to improve current modelling tools. Sap flow measurements provide accurate daily tree transpiration estimates, whereas measurements of soil heat fluxes could be used to measure soil evaporation. The Bowen Ratio method (Verma, 1990) applied on fluxes measured in and above the canopy together with footprint analyses, and scintillometer experiments (De Bruin et al., 1995) are all useful methods to collect time series of the $W U$ components necessary for model development, calibration and application. Determination of the temporal variation of $E T$ must also proceed with the modelling of its spatial variation.

Concerning the effect of land use on $W U$, further studies should focus also on the regional scale, either by using a GISmodelling approach or applying remote sensing techniques (Verstraeten et al., 2005). Nevertheless as illustrated in this study stand scale models can deliver major support to the interpretation of remotely sensed derived $W U$ values, both in space and time.

\section{Appendix A}

Abbreviations used throughout the text

\begin{tabular}{|c|c|}
\hline$\alpha(h)$ & Root water reduction function [-]; \\
\hline$\Delta$ & Slope of the vapour pressure curve $\left[\mathrm{kPa}^{\circ} \mathrm{C}^{-1}\right]$; \\
\hline$\gamma$ & Psychometric constant $\left[\mathrm{kPa}^{\circ} \mathrm{C}^{-1}\right]$ \\
\hline$a$ & Shape parameter [-]; \\
\hline$c$ & Vegetation solar radiation interception [-]; \\
\hline$C D$ & Coefficient of determination [-]; \\
\hline$E_{\text {act }}$ & Actual soil evaporation $[\mathrm{mm}]$ \\
\hline$E_{p}$ & Potential soil evaporation [mm]; \\
\hline$e_{a}$ & Actual vapour pressure $[\mathrm{kPa}]$; \\
\hline$e_{s}$ & Saturation vapour pressure $[\mathrm{kPa}]$ \\
\hline$E T_{0}$ & Reference crop evapotranspiration $[\mathrm{mm}]$; \\
\hline$E T_{\text {act }}$ & Actual evapotranspiration [mm]; \\
\hline$E T_{c}$ & Potential crop evapotranspiration [mm]; \\
\hline$G_{0}$ & Soil heat flux $\left[\mathrm{MJ} \mathrm{m}^{-2} \mathrm{~d}^{-1}\right]$ \\
\hline $\mathrm{H}_{0}$ & Null hypothesis; \\
\hline $\mathrm{H}_{a}$ & Alternative hypothesis; \\
\hline$h$ & Soil pressure head [m]; \\
\hline$h_{0}$ & Moisture tension when water extraction starts [-]; \\
\hline$h_{c}$ & $\begin{array}{l}\text { Moisture tension when water extraction } \\
\text { starts to reduce [-]; }\end{array}$ \\
\hline HDP & Hemispherical Digital Photograph imagery \\
\hline$h_{F C}$ & Moisture tension at field capacity [m]; \\
\hline$h_{W P}$ & Moisture tension at wilting point [m]; \\
\hline INT & Canopy interception evaporation $[\mathrm{mm}]$; \\
\hline$K_{c}$ & Crop factor $[-]$ \\
\hline$K_{\text {sat }}$ & Saturated hydraulic conductivity $\left[\mathrm{m} \mathrm{d}^{-1}\right]$; \\
\hline$L$ & Maximum soil depth [m]; \\
\hline LAI & Leaf-Area Index $\left[\mathrm{m}^{2} \mathrm{~m}^{-2}\right]$ \\
\hline$M E$ & Model efficiency [-]; \\
\hline$n$ & $\begin{array}{l}\text { Amount of available measurements in the } \\
\text { considered time interval [-]; }\end{array}$ \\
\hline $\bar{O}$ & $\begin{array}{l}\text { Average of the observed soil moisture values } \\
{\left[\mathrm{cm}^{3} \mathrm{~cm}^{-3}\right]}\end{array}$ \\
\hline$O_{i}$ & $\mathrm{i}^{\text {th }}$ measured soil moisture value $\left[\mathrm{cm}^{3} \mathrm{~cm}^{-3}\right]$; \\
\hline$P$ & $\mathrm{i}^{\text {th }}$ simulated soil moisture value $\left[\mathrm{cm}^{3} \mathrm{~cm}^{-3}\right]$; \\
\hline PA & Profile analysis; \\
\hline PAI & Plant Area Index $\left[\mathrm{m}^{2} \mathrm{~m}^{-2}\right]$ \\
\hline RMSE & Root Mean Square Error $\left[\mathrm{cm}^{3} \mathrm{~cm}^{-3}\right]$; \\
\hline$R_{n}$ & Net radiation $\left[\mathrm{MJ} \mathrm{m}^{-2} \mathrm{~d}^{-1}\right]$ \\
\hline$S F$ & Stemflow $\left[\mathrm{mm} \mathrm{d}^{-1}\right]$ \\
\hline$S(h, z)$ & $\begin{array}{l}\text { Actual root water extraction function } \\
{\left[\mathrm{mm} \mathrm{d}^{-1}\right]}\end{array}$ \\
\hline$S_{\max }$ & $\begin{array}{l}\text { Maximum root water extraction function } \\
{\left[\mathrm{mm} \mathrm{d}^{-1}\right]}\end{array}$ \\
\hline$S M C$ & Soil moisture content $\left[\mathrm{cm}^{3} \mathrm{~cm}^{-3}\right]$ \\
\hline$T$ & Air temperature $2 \mathrm{~m}$ above the surface $\left[{ }^{\circ} \mathrm{C}\right]$; \\
\hline$T_{\text {act }}$ & Actual plant transpiration [mm]; \\
\hline$T F$ & Throughfall $\left[\mathrm{mm} \mathrm{d}^{-1}\right]$ \\
\hline TDR & Time domain reflectometry; \\
\hline$T_{p}$ & Potential plant transpiration [mm]; \\
\hline & Wind velocity $2 \mathrm{~m}$ above the surface $\left[\mathrm{m} \mathrm{s}^{-1}\right]$; \\
\hline WAVE & $\begin{array}{l}\text { Water and Agrochemicals in Vadose } \\
\text { Environment; }\end{array}$ \\
\hline$W U$ & Water use $[\mathrm{mm}]$ \\
\hline$z$ & Soil depth $[\mathrm{m}]$ \\
\hline
\end{tabular}


Acknowledgements. The authors are grateful to the Flemish Community for having provided the funds to conduct this research (Vlaams Impulsprogramma Natuurontwikkeling, contract number VLINA9906). Without the technical support of the Department of Land Management (Katholieke Universiteit Leuven) and the Institute for Forestry and Game Management (IBW) the study would never have been feasible. We also like to thank the reviewers for their constructive comments, suggestions and time spent reviewing the manuscript.

Edited by: S. Uhlenbrook

\section{References}

Allen, R. G., Pereira, L. S., Raes, D., and Smith, M.: Crop evapotranspiration. Guidelines for computing crop water requirements, FAO Irrigation and Drainage Paper, Rome, 56, 1998.

Anderson, M. P. and Woessner, W. W.: Applied Groundwater Modelling Simulation of Flow and Advective Transport, University Press, Cambridge, 296 pp., 1992.

Bastiaanssen, W. G. M., Pelgrum, H., Roerink, G., and Soeterink, K.: Soil moisture conditions in the Netherlands during the summer of 1995 interpreted from satellite measurements, in: GIS and remote sensing techniques in land- and water management, edited by: van Dijk, A. and Bos, M. G., Kluwer, Amsterdam, 69-86, 2001.

Bosch, J. M. and Hewlett, J. D.: A review of catchment experiments to determine the effect of vegetation changes on water yield and evapotranspiration, J. Hydrol., 55, 3-23, 1982.

Belmans, C., Wesseling, J. G., and Feddes, R. A.: Simulation model of the water balance of a cropped soil: SWATRE, J. Hydrol., 63, 271-286, 1983.

Brauda, I., Varado, N., and Olioso, A.: Comparison of root water uptake modules using either the surface energy balance or potential transpiration, J. Hydrol., 301, 267-286, 2005.

Cameira, M. R., Fernando, R. M., Ahuja, L., and Pereira, L.: Simulating the fate of water in field soil-crop environment, J. Hydrol., in press, 1-24, 2005.

Cermák, J., Ulehla, J., Kucera, J., and Penka, M.: Sap flow rate and transpiration dynamics in full grown oak (Quercus robur L.) in floodplain forest exposed to seasonal floods as related to potential evapotranspiration and tree dimensions, Biol. Plantarum (Praha), 24(6), 446-460, 1982.

Cermák, J. and Nadezhdina, N.: Sapwood as the scaling parameter - defining according to xylem water content or radial pattern of sap flow? Annales des Sciences forestières, 55, 509-521, 1998.

Choisnel, E., de Villele, O., and Lacroze, F.: Une approche uniformisée du calcul de l'évapotranspiration potentielle pour l'ensemble des pays de la communauté européenne, Commission of the European communities, Brussels-Luxemburg, 176 pp., 1992.

Chow, V. T., Maidment, D. R., and Mays, L. W.: Applied Hydrology. McGraw-Hill international editions, Singapore, 572 pp., 1993.

Coners, H. and Leuschner, C.: In situ measurement of fine root water absorption in three temperate tree species - Temporal variability and control by soil and atmospheric factors, Basic and Applied Ecol., 6, 395-405, 2005.
De Bruin, H. A. R., van den Hurk, B. J. J. M., and Kohiesk, W.: The scintillation method tested over a dry vineyard area, BoundaryLayer Meteorol., 76, 25-40, 1995.

Dolman, A. J., Moors, E. J., Elbers, J. A., and Snijders, W.: Evaporation and surface conductance of three temperate forests in the Netherlands, Ann. Sci. For., 55, 255-270, 1998.

Dolman, H., Moors, E., Elbers, J., Snijders W., and Hamaker, P.: Het waterverbruik van bossen in Nederland, Alterra Wageningen (in Dutch), 2000.

Doorenbos, J. and Pruitt, W. O.: Crop water requirements, FAO Irrigation and Drainage Paper, 24, Rome, Italy, 1977.

Ducheyne, S., Schadecka, N., Vanongeval, L., Vandendriessche, H., and Feyen, J.: Assessment of the parameters of a mechanistic soil-crop-nitrogen simulation model using historic data of experimental field sites in Belgium, Agric. Water Manag., 51, 53-78, 2001.

Edraki, M., So, H. B., and Gardner, E. A.: Water balance of Swamp Mahogany and Rhodes grass irrigated with treated sewage effluent, Agric. Water Manag., 67, 157-171, 2004.

Feddes, R. A., Kowalik, P. J., and Zazadyn, H.: Simulation of field water use and crop yield, Simulation Monographs, PUDOC, Wageningen, the Netherlands, 189 pp., 1978.

Gochis, D. J. and Cuenca, R. H.: Plant water use and crop curves for hybrid poplars, J. Irrigation and Drainage Engineering, 126, 206-214, 2000.

Hall, R. L. and Roberts, J. M.: Hydrological aspects of new broadleaf plantations, SEESOIL, 6, 2-38, 1990.

Homaee, M., Dirksen, C., and Feddes, R. A: Simulation of water uptake II. Non-uniform transient salinity using different macroscopic reduction functions, Agric. Water Manag., 57, 89-110, 2002a.

Homaee, M., Feddes, R. A., and Dirksen, C.: Simulation of water uptake II. Non-uniform transient water stress using different reduction functions, Agric. Water Manag., 57, 111-126, $2002 \mathrm{~b}$.

Hupet, F. and Vanclooster, M.: Comments on "Water flux estimates from a Belgian Scots pine stand: a comparison of different approaches" by Meiresonne, L., Sampson, D. A., Kowalski, A. S., Janssens, I. A., Nadezhdina, N., Cermák, J., Van Slycken, J., and Ceulemans, R., J. Hydrol., 2003, 230-252, J. Hydrol., 291, 150$153,2004$.

Huygen, J., Van Dam, J. C., Kroes, J. G., and Wesseling, J. G.: SWAP 2.0: input and output manual, Wageningen Agricultural University, and DLO-Staring Centrum, Wageningen, 52 pp., 1997.

ICP: International Co-operative Programme on Assessment and Monitoring of Air Pollution Effects on Forests, http://www. icp-forests.org, 2005.

Jobson, J. D.: Applied multivariate data analysis. 2: Categorical and multivariate methods, Springer New York, 1992.

Johnson, R. A. and Wichern, D. W.: Applied multivariate statistical analysis, Prentice-Hall International, Inc, 1992.

Jonckheere, I., Fleck, S., Nackaerts, K., Muys, B., Coppin, P., Weiss, M., and Baret, F.: Review of methods for in situ leaf area index determination. Part I. Theories, sensors and hemispherical photography, Agric. For. Meteorol., 121, 19-35, 2004a.

Jonckheere, I., Nackaerts, K., Muys, B., and Coppin, P.: Optimalisation of in-situ LAI determination by means of forest stand models, in: Proceedings of International Conference on Modelling Forest production, 19-23 April 2004, Vienna, Austria, 
184-188, 2004b.

Kang, Y., Wang, Q.-G., and Liu, H.-J.: Winter wheat canopy interception and its influence factors under sprinkler irrigation, Agric. Water Manag., 74, 189-199, 2005.

Klute, A. (Ed.): Methods of soil analysis, Part 1, Physical and mineralogical methods, 2nd ed. Agronomy 9(2), American Society of Agronomy, Madison, Wisconsin, USA, 1986.

Knotters, M. and Bierkens, M. F. P.: Physical basis of time series models for water table depths, Water Resour. Res., 36(1), 181188, 2000.

Ladekarl, U. L.: Estimation of the components of soil water balance in a Danish oak stand from measurements of soil moisture using TDR, For. Ecol. Manag., 104, 227-238, 1998.

Larcher, W.:Water economy in plant communities, in: Physiological Plant Ecology, 2nd ed., edited by: Larcher, W., Springer, Berlin, 1995.

Meiresonne, L., Nadezhdina, N., Cermák, J., Van Slycken, J., and Ceulemans, R.: Measured sap flow and simulated transpiration from a poplar stand in Flanders (Belgium), Agric. For. Meteorol., 96, 165-179, 1999.

Meiresonne, L., Sampson, D. A., Kowalski, A. S., Janssens, I. A., Nadezhdina, N., Cermák, J., Van Slycken, J., and Ceulemans, R.: Water flux estimates from a Belgian Scots pine stand: a comparison of different approaches, J. Hydrol., 270, 230-252, 2003.

Mohren, G. M. J. and van de Veen, J. R.: Forest growth in relation to site conditions. Application of the model FORGRO to the Solling spruce site, Ecol. Model., 83(1-2), 173-183, 1995.

Mualem, Y.: A new model for predicting the hydraulic conductivity of unsaturated porous media, Water Resour. Res., 12(3), 513522, 1976.

Nackaerts, K.: Modeling of leaf area index as a scale-integrated indicator for forest monitoring, PhD-Thesis No. 529, Faculty of Agricultural and Applied Biological Sciences, Katholieke Universiteit Leuven, 224 pp., 2002.

Nackaerts, K., Wagendorp, T., Coppin, P., Muys, M., and Gombeer, R.: A correction of indirect Leaf Area Index measurements for a non random distribution of needles on shoots, in: Proceedings of the International Conference on Systems and Sensors for the New Millennium of The International Symposium on Spectral Sensing Research, 31 October-4 November, 1999, Las Vegas Nevada, USA, 2001.

Nadezhdina, N. and Cermák, J.: Instrumental methods for studies of structure and function of root systems of large trees, J. Experiment. Bot., 54(387), 1511-1521, 2003.

Nizinski, J., Morand, D., and Saugier, B.: Variation of stomatal resistance with leaf age in Quercus petraea: effect on the soilwater balance of an oak forest, Tree Physiology, 46, 429-432, 1989.

Peck, A. and Mayer, H.: Einfluss von Bestandesparametern auf die Verdunstung von Wäldern (in German), Forstwiss. Centrabl., $115,1-9,1996$.

Penning de Vries, F. W. T. and Van Laar, H. H.: Simulation of plant growth and crop production, Simulation Monographs, PUDOC, Wageningen, The Netherlands, 1982.

Roberts, J. M. and Rosier, P. T. W.: Comparative estimates of transpiration of ash and beech forests at chalk site in southern Britain, J. Hydrol., 162, 229-245, 1994.

Samson, R., Follens, S., and Lemeur, R.: Scaling leaf photosynthesis to canopy in a mixed deciduous forest. I. Model description,
Silva Gandavensis, 62, 1-21, 1997.

Samson, R.: An experimental and modelling approach to the actual evapotranspiration in a mixed forest ecosystem (Experimental forest Aelmoeseneie at Gontrode), PhD-thesis, Universiteit Gent, 294 pp., 2001.

SAS/STAT software: Version 6, 4th edn., Volume 1, Cary, NC: SAS Institute Inc, 1992.

Schaap, M. G., Bouten, W., and Verstraten, J. M.: Forest floor water content dynamics in a Douglas fir stand, J. Hydrol., 201, 367383, 1997.

Spitters, C. J. T.: Separating the diffuse and direct component of global radiation and its implications for modelling canopy photosynthesis. Part II., Calculation of canopy photosynthesis, Agric. For. Meteorol., 38, 231-242, 1986.

Spitters, C. J. T, Toussaint H. A. J., and Goudriaan, J.: Separating the diffuse and direct component of global radiation and its implications for modelling canopy photosynthesis. Part I., Components of incoming solar radiation, Agric. For. Meteorol., 38, 217-229, 1986.

Spitters, C. J. T., van Keulen, H., and Van Kraailingen, D. W. G.: A simple but universal crop growth simulation model, SUCROS87, in: Simulation and systems management in crop protection, edited by: Rabbinge, R., Van Laar, H., and Ward, S., Simulation Monographs, PUDOC, Wageningen, The Netherlands, 1988.

Timmerman, A., Mertens, J., Kroes, J. G., and Vandenbosch, T.: Eindrapport projectonderdeel B. Watermanagement op bedrijfsniveau: "integratie van het beregeningsadviessysteem met het peil- en nutriëntenbeheer". Interregprogramma voor het Benelux Middengebied (in Dutch), 113 pp., 2001.

Topp, G. C., Davis, J. L., and Annan, A. P.: Electromagnetic determination of soil water content: Measurements in coaxial transmission lines, Water Resour. Res., 16, 574-582, 1980.

Vanclooster, M., Viaene, P., Diels, J., and Christiaens, K.: WAVE, a mathematical model for simulating water and agrochemicals in the soil and vadose environment. Reference and user's manual, Release 2.0, Institute for Land and Water Management, Katholieke Universiteit Leuven, Leuven, 147 pp., 1994.

Vanclooster, M., Viaene, P., Diels, J., and Feyen J.: A deterministic evaluation analysis applied to an integrated soil-crop model, Ecol. Mod., 81, 183-195, 1995.

Vanclooster, M., Viaene, P. Christiaens, K., and Ducheyne, S.: WAVE, a mathematical model for simulating water and agrochemicals in the soil and the vadose environment. Reference and user's manual, release 2.1. Institute for Land and Water Management, Katholieke Universiteit Leuven, Leuven, 15 pp., 1996.

Vanderborght, J., Vanclooster, M., Timmerman, A., Seuntjens, P., Mallants, D., Kim, D.-J., Jacques, D., Hubrechts, L. Gonzalez, C., Feyen, J., Diels, J., and Deckers, J.: Overview of inert tracer experiments in key Belgian soil types: Relation between transport and soil morphological and hydraulic properties, Water Resour. Res., 37(12), 2873-2888, 2001.

van Genuchten, M.: A closed-form equation for predicting the hydraulic conductivity of soil, Soil Science Society of American Journal, 44, 892-898, 1980.

van Genuchten, M., Leije, F. J., and Yates, S. R.: The RETC code for quantifying the hydraulic functions of unsaturated soils, IAGDW12933934, US Environmental Protection Agency, ADA, Oklahoma 74820, 1991.

van Keulen, H., Penning de Vries, F. W. T., and Drees, E. M.: A 
summary model for crop growth, in: Simulation of plant growth and crop production, edited by: Penning de Vries, F. W. T. and Van Laar, H., Simulation Monographs, PUDOC, Wageningen, the Netherlands, 87-97, 1982.

Verma, S. B.: Micrometeorological Methods for Measuring Surface Fluxes of Mass and Energy, Remote Sens. Rev., 5(1), 99-115, 1990.

Verstraeten, W. W., Minnaert, M., Meiresonne, L., Lemeur. R., Devos., B, Van Slycken, J., Deckers, J., Muys, B., and Feyen, J.: Kwantitatieve analyse van de verdamping van bossen in vergelijking met weide en akkerlaned (in Dutch), VLINA-9906, 225 pp., 2001.

Verstraeten, W. W., Veroustraete, F., and Feyen, J.: Estimating evapotranspiration of European forests from NOAA-imagery at satellite overpass time: Towards an operational processing chain for integrated optical and thermal sensor data products, Remote Sens. Environ., 96(2), 256-276, 2005.
Warren, J. M., Meinzer, F. C., Brooks, J. R., and Domec, J. C.: Vertical distribution of soil water storage and release dynamics in Pacific Northwest coniferous forests, Agric. For. Meteorol., 130, 39-58, 2005.

Weiss, M., Baret, F., Smith, G. J., Jonckheere, I., and Coppin, P.: Review of methods for in situ leaf area index (LAI) determination. Part II. Estimation of LAI, errors and sampling, Agric. For. Meteorol., 121, 37-53, 2004.

White, M. A.: Monitoring en modelling growing season dynamics, PhD-thesis, University of Montana, 9, 345, 1999.

Wolfringer, R. and Chang, M.: Comparing SAS® GLM and MIXED Procedures for Repeated Measures. SUGI Proceedings, 1995, SAS Institute Inc., Cary, NC, 1995.

Zhao, C., Feng, Z., and Chen, G.: Soil water balance simulation of alfalfa (Medicago sativa L.) in the semiarid Chinese Loess Plain, Agric. Water Manag., 69, 101-114, 2004. 